Review

\title{
Excessive Innate Immunity Steers Pathogenic Adaptive Immunity in the Development of Theiler's Virus-Induced Demyelinating Disease
}

\author{
Byung S. Kim
}

check for

updates

Citation: Kim, B.S. Excessive Innate Immunity Steers Pathogenic Adaptive Immunity in the Development of Theiler's Virus-Induced Demyelinating Disease. Int. J. Mol. Sci. 2021, 22, 5254 https://doi.org/10.3390/ ijms22105254

Academic Editors: Antonietta Bernardo, Sergio Visentin and William A. Banks

Received: 15 April 2021

Accepted: 13 May 2021

Published: 17 May 2021

Publisher's Note: MDPI stays neutral with regard to jurisdictional claims in published maps and institutional affiliations.

Copyright: (C) 2021 by the author. Licensee MDPI, Basel, Switzerland. This article is an open access article distributed under the terms and conditions of the Creative Commons Attribution (CC BY) license (https:// creativecommons.org/licenses/by/ $4.0 /)$.
Department of Microbiology-Immunology, Northwestern University Feinberg School of Medicine, Chicago, IL 60611, USA; bskim@northwestern.edu; Tel.: +1-312-503-8693

\begin{abstract}
Several virus-induced models were used to study the underlying mechanisms of multiple sclerosis (MS). The infection of susceptible mice with Theiler's murine encephalomyelitis virus (TMEV) establishes persistent viral infections and induces chronic inflammatory demyelinating disease. In this review, the innate and adaptive immune responses to TMEV are discussed to better understand the pathogenic mechanisms of viral infections. Professional (dendritic cells (DCs), macrophages, and B cells) and non-professional (microglia, astrocytes, and oligodendrocytes) antigenpresenting cells (APCs) are the major cell populations permissive to viral infection and involved in cytokine production. The levels of viral loads and cytokine production in the APCs correspond to the degrees of susceptibility of the mice to the TMEV-induced demyelinating diseases. TMEV infection leads to the activation of cytokine production via TLRs and MDA- 5 coupled with NF- $\mathrm{kB}$ activation, which is required for TMEV replication. These activation signals further amplify the cytokine production and viral loads, promote the differentiation of pathogenic Th17 responses, and prevent cellular apoptosis, enabling viral persistence. Among the many chemokines and cytokines induced after viral infection, IFN $\alpha / \beta$ plays an essential role in the downstream expression of costimulatory molecules in APCs. The excessive levels of cytokine production after viral infection facilitate the pathogenesis of TMEV-induced demyelinating disease. In particular, IL- 6 and IL- $1 \beta$ play critical roles in the development of pathogenic Th17 responses to viral antigens and autoantigens. These cytokines, together with TLR2, may preferentially generate deficient FoxP3 ${ }^{+} \mathrm{CD}^{2} 5^{-}$regulatory cells converting to Th17. These cytokines also inhibit the apoptosis of TMEV-infected cells and cytolytic function of $\mathrm{CD}^{+} \mathrm{T}$ lymphocytes (CTLs) and prolong the survival of B cells reactive to viral and self-antigens, which preferentially stimulate Th17 responses.
\end{abstract}

Keywords: virus; demyelination; inflammation; Th cells; FoxP3 ${ }^{+} \mathrm{CD} 4^{+} \mathrm{T}$ cells

\section{Theiler's Virus-Induced Demyelinating Disease as an Infectious Model of Multiple Sclerosis}

Multiple sclerosis (MS) is an immune-mediated neurological disease characterized by demyelination in the white matter of the brain and spinal cord [1]. Although the cause of MS is unknown, infectious agents may be involved in the initial infliction of tissue damage, leading to autoimmunity. A possible viral association is suggested by epidemiological studies [2,3] and by the detection of viral antigens and virus-specific antibodies in the majority of MS patients [4-7]. Several autoimmune and virus-induced models have been used to study the underlying mechanisms of this disease [8-12]. Among virus-induced models, Theiler's murine encephalomyelitis virus (TMEV)-induced demyelination provides an excellent infectious model because of the similarities in the pathogenesis $[9,10,13,14]$. In addition, Theiler's virus appears to be an emerging human virus group, called Saffold virus, which infects greater than $90 \%$ human populations [15-17]. Therefore, it is possible that MS is triggered by a combination of genetic prevalence and nonspecific bystander 
chronic viral infections resulting in the development of skewed pathogenic $\mathrm{T}$ cell types reactive to viral and self-antigens.

TMEV is a common enteric pathogen in mice and belongs to the family of picornavirus $[18,19]$. Two major subgroups of TMEV have been identified based on varying biological characteristics such as neurovirulence and antigenicity. The first subgroup of TMEV includes GDVII and FA viruses, which cause rapid and fatal encephalitis. The second subgroup, known as Theiler's original viruses, includes the BeAn8386 and DA strains. Intracerebral inoculation of Theiler's original viruses into susceptible mice causes a biphasic neurological disease [13,19-21]. Mice exposed to TMEV orally do not develop clinical symptoms and show reduced demyelinating disease after intracerebral inoculation of the virus, suggesting the infection route is important for the pathogenesis [22]. In fact, TMEV infection is spread widely via the fecal-oral route among wild mouse populations, yet these infected mice rarely develop clinical disease [23]. The early, acute phase displays flaccid limb paralysis and degeneration of neurons (poliomyelitis). The late phase exhibits chronic, inflammatory demyelination $[20,21]$. The BeAn strain, in contrast to the DA strain, is known to induce a clinically undetectable level of the early phase disease although it manifests as a severe late phase disease $[13,20]$. TMEV infection is also known to induce epilepsy and myocarditis depending on the injection sites and/or mouse strains [24,25]. However, this review focuses on the induction of demyelinating disease. Several hypotheses have been proposed to explain virus-induced demyelination. These include: (1) "bystander" damage of myelin $[26,27]$ as a consequence of the host immune response against TMEV antigens; (2) induction of autoimmunity (via epitope spreading) to myelin proteins released by viral damage to the CNS [14,28,29]; and/or (3) induction and propagation of pathogenic antiviral and anti-self-immune responses by chronic overstimulations via pathogen pattern recognition receptors $[14,30]$.

SJL/J (SJL) mice $\left(\mathrm{H}-2^{\mathrm{s}}\right)$ represent a prototypical susceptible mouse strain and C57BL/6 (B6) mice $\left(\mathrm{H}-2^{\mathrm{b}}\right)$ represent a prototypical resistant mouse strain against both viral persistence and the development of demyelinating disease [31,32]. Genetic studies of susceptibility to TMEV-induced demyelinating disease (TMEV-IDD) indicated that one of the important susceptibility loci is linked in the $H-2 D$ gene complex, suggesting the association with $H-2 D$-restricted $\mathrm{CD}^{+} \mathrm{T}$ cell response [33,34]. However, $\mathrm{CD} 8^{+} \mathrm{T}$ cells generated in response to TMEV BeAn strain in susceptible SJL mice are restricted with the H-2K locus [35]. F1 $\left(\mathrm{H}-2^{\mathrm{b} / \mathrm{s}}\right)$ of $\mathrm{B} 6$ and SJL mice are relatively resistant to TMEV-IDD and preferentially develop $\mathrm{H}-2 \mathrm{D}^{\mathrm{b}}$-restricted $\mathrm{CD} 8^{+} \mathrm{T}$ cells of resistant $\mathrm{B} 6$ mice, not the $\mathrm{H}-2 \mathrm{~K}^{\mathrm{s}}$-restricted $\mathrm{CD} 8^{+}$ $\mathrm{T}$ cells of susceptible SJL mice $[27,36,37]$. However, B6.S mice, similar to B10.S mice bearing $\mathrm{H}-2^{\mathrm{s}}$, are relatively resistant to TMEV-IDD, indicating that other background genes may play a critical role in determining the susceptibility [38]. The major mouse strains used, susceptibility to TMEV, and their MHC and the background genes are shown in Table 1. The association with background genes is consistent with the previous genetic study indicating that TMEV persistence level in the central nervous system (CNS) is associated with non-MHC-linked genes on chromosomes 10, 14 and 18 [39-41]. In addition, TMEV persistence in the CNS appears to play an important role in the pathogenesis of demyelination [42-48]. However, the level of antiviral immunity is critical for the pathogenesis of demyelinating disease rather than the viral persistence levels as shown with TMEV-capsid transgenic mice, which are immunologically tolerant to the capsid antigens [49]. Therefore, it appears that viral persistence facilitates the production of continuous inflammatory cytokines and the consequent lasting pathogenic $\mathrm{T}$ cell responses for the development of TMEV-IDD. In this review, levels and types of innate and adaptive immune responses to TMEV will be analyzed in conjunction with the viral load to better understand the pathogenic mechanisms of virus-induced demyelinating disease. 
Table 1. Properties of major mouse strains and transgenic mice used in this review.

\begin{tabular}{|c|c|c|c|c|c|}
\hline Mouse Strains & Background Genes & MHC & Susceptibility & Th Epitopes & CTL Epitopes \\
\hline SJL & SJL & $\mathrm{H}-2^{\mathrm{s}}$ & Yes & $\begin{array}{c}\mathrm{VP} 2_{72-86}, 3 \mathrm{D}_{21-36} \\
\mathrm{VP} 3_{24}-37 \\
\mathrm{VP} 1_{233}-250 \\
\end{array}$ & $\begin{array}{l}\mathrm{VP}_{159-166} \\
\mathrm{VP}_{173-181} \\
\mathrm{VP} 1_{11-20}\end{array}$ \\
\hline C57BL/6 (B6) & B6 & $\mathrm{H}-2^{\mathrm{b}}$ & No & $\begin{array}{l}\mathrm{VP} 2_{206}-220 \\
\mathrm{VP} 4_{25-38}\end{array}$ & $\mathrm{VP} 2121-130$ \\
\hline B10.S & B10 & $\mathrm{H}-2^{\mathrm{s}}$ & No/weak & $\begin{array}{c}\mathrm{VP} 2_{72-86}, 3 \mathrm{D}_{21-36} \\
\mathrm{VP} 3_{24}-37 \\
\mathrm{VP} 1_{233}-250\end{array}$ & $\begin{array}{l}\mathrm{VP}_{159-166} \\
\mathrm{VP}_{173-181} \\
\mathrm{VP} 1_{11-20}\end{array}$ \\
\hline B6.S & B6 & $\mathrm{H}-2^{\mathrm{s}}$ & No/weak & $\begin{array}{c}\mathrm{VP} 2_{72-86}, 3 \mathrm{D}_{21-36} \\
\mathrm{VP} 3_{24}-37 \\
\mathrm{VP} 1_{233}-250\end{array}$ & $\begin{array}{l}\mathrm{VP} 3_{159-166} \\
\mathrm{VP} 3_{173-181} \\
\mathrm{VP} 1_{11-20}\end{array}$ \\
\hline (SJLxB6)F1 & $\mathrm{SJL}+\mathrm{B} 6$ & $\mathrm{H}-2^{\mathrm{s}} / \mathrm{H}-2^{\mathrm{b}}$ & No/weak & $\begin{array}{c}\mathrm{VP} 2_{206}-220 \\
\mathrm{VP}_{25}-38 \\
\mathrm{VP} 2_{72-86}, 3 \mathrm{D}_{21-36}\end{array}$ & $\begin{array}{l}\mathrm{VP} 2_{121-130} \\
\mathrm{VP} 3_{159-166} \\
\mathrm{VP} 3_{173}-181 \\
\mathrm{VP} 1_{11-20}\end{array}$ \\
\hline Transgene & Background Genes & MHC & Susceptibility & Th Epitopes & CTL Epitopes \\
\hline VP2-TCR-Tg & SJL & $\mathrm{H}-2^{\mathrm{s}}$ & $>$ Yes & $>>>V P 2_{72}-86$ & $\begin{array}{c}<<\mathrm{VP} 3_{159-166} \\
\mathrm{VP}_{173-181} \\
\mathrm{VP} 1_{11-20}\end{array}$ \\
\hline TMEV P1-Tg & SJL & $\mathrm{H}-2^{\mathrm{s}}$ & No & $3 \mathrm{D}_{21-86}$ & \\
\hline TMEV P2/P3-Tg & SJL & $\mathrm{H}-2^{\mathrm{s}}$ & Yes & $\begin{array}{l}\mathrm{VP} 2_{72}-86 \\
\mathrm{VP} 3_{24}-37 \\
\mathrm{VP} 1_{233}-250\end{array}$ & $\begin{array}{l}\mathrm{VP} 3_{159-166} \\
\mathrm{VP}_{173-181} \\
\mathrm{VP} 1_{11-20}\end{array}$ \\
\hline
\end{tabular}

\section{Factors Affecting Permissiveness to TMEV Infection}

\subsection{Antigen-Presenting Cells}

Many different cell types are permissive to TMEV infection, including neurons, oligodendrocytes, microglia, and astrocytes in the CNS, and dendritic cells, macrophages, and $B$ cells of peripheral and infiltrating populations [30,50-53]. Non-professional antigenpresenting cells (APCs) in the CNS of TMEV-infected SJL mice, such as microglia and astrocytes, are capable of presenting antigens to both TMEV- and CNS autoantigen-specific T cell hybridomas and clones [54-56]. Furthermore, microglia and/or infiltrating macrophages in the CNS are a major cell population supporting viral persistence during chronic infection [56-58]. Virus replication is significantly higher in microglia from naïve SJL mice and the viral load is also greater in microglia from TMEV-infected SJL mice, compared to those cells from B6 mice [59]. In addition, differentiated/activated macrophages or astrocytes are much more permissive to TMEV infection/replication, providing the source of viral persistence in the CNS [60-62]. Consequently, the cytokine production level in microglia from SJL mice is higher compared to those from B6 mice. However, the levels of costimulatory molecule expression, and the ability to stimulate allogeneic $\mathrm{T}$ cells, are significantly lower in TMEV-infected SJL mice than in B6 mice [38,63]. These differences in the intrinsic properties of antigen-presenting cells for viral infection, replication and resulting innate cytokine production are likely to contribute to viral persistence, cellular infiltration to the CNS and consequent development of demyelinating disease. Moreover, these APCs, including macrophages/microglia, dendritic cells, and B cells in the CNS and periphery, appear to play additional important roles in stimulating $\mathrm{T}$ cells associated in the pathogenesis [30,63-65].

Further studies using B6.S mice, which carry the H-2 ${ }^{\mathrm{s}}$ with the resistant C57BL/6 background genes, are free from TMEV-IDD and display lower viral loads in the spinal cord compared to susceptible SJL mice [38]. Interestingly, viral infectivity and/or replication in glia and antigen-presenting cells (APCs) from TMEV-IDD resistant B6.S, B6, and F1(B6XSJL) 
mice are significantly lower compared to these SJL cells [37,59]. In vitro studies using APCs from B6.S and SJL mice show that TLR2, 3, 4, and 7-mediated signaling augment viral infection leading to the preferential differentiation of the pathogenic Th17 cell type in susceptible SJL mice $[38,66]$. Microglia and macrophages from susceptible SJL mice produce higher levels of IL-6 and IL-1 after TMEV infection compared to those cells from either B6, B6.S, or B10.S [67-69]. These observations indicate that the level of viral infectivity/replication controlled by non-MHC genes plays a critical role in the pathogenesis of chronic viral diseases. Taken together, these results strongly suggest that the viral replication levels in APCs critically affect the induction of protective vs. pathogenic Th cell types via the signaling of pattern recognition receptors for innate immune responses (Figure 1).
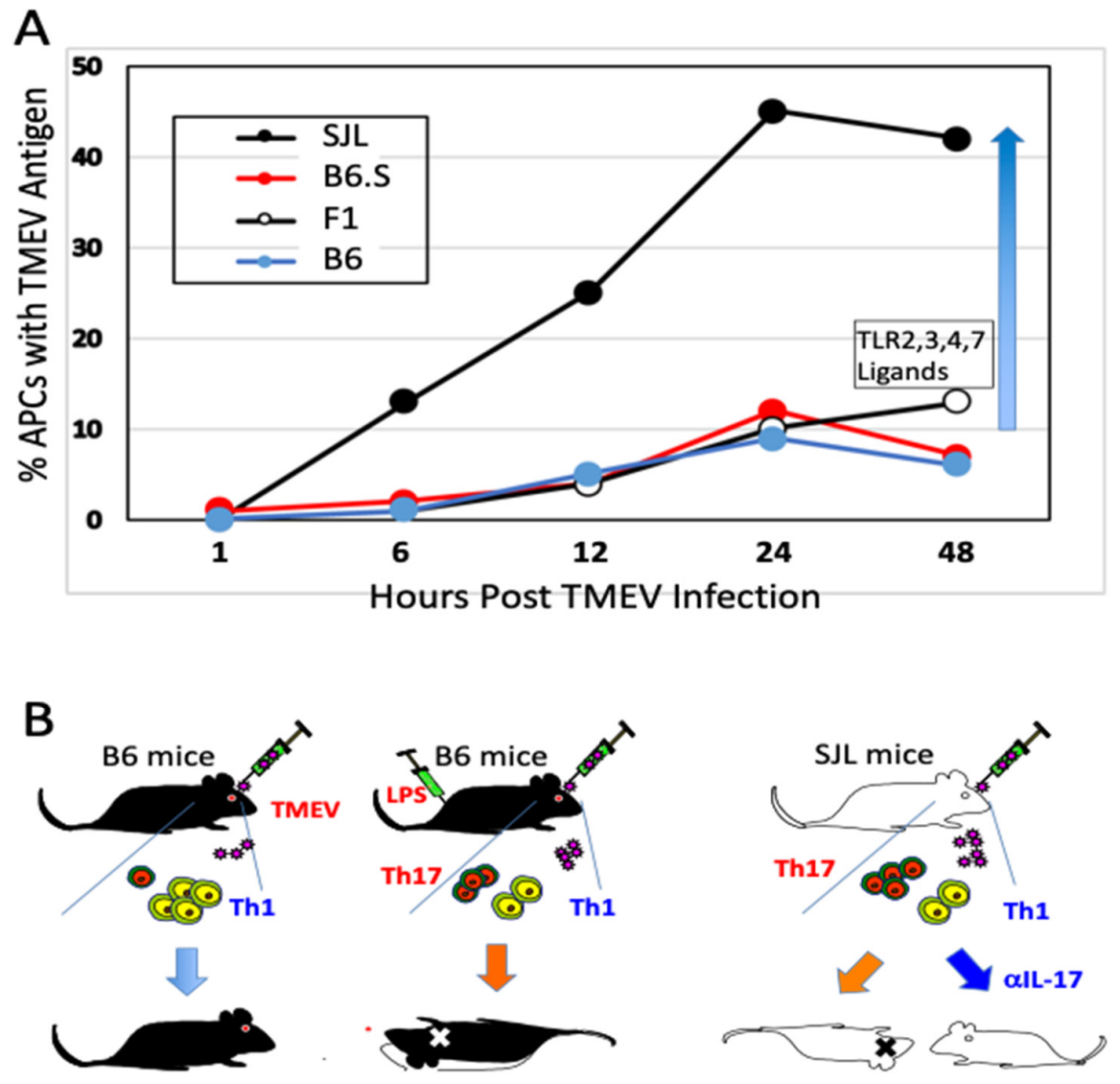

Figure 1. Permissiveness of antigen-presenting cells to Theiler's murine encephalomyelitis virus (TMEV) infection correlates with susceptibility to the pathogenesis of demyelinating disease. (A) Susceptibility of antigen-presenting cells to TMEV infection/replication is directly associated with the development of chronic demyelinating disease. The elevated viral infection/replication leads to elevated inflammatory cytokine production (such as IL-6 and IL-1) which favors stimulation of pathogenic Th17 response over protective Th1 response. (B) Levels of Th17 determine the development of TMEV-induced demyelinating disease. Genetically resistant B6 mice induce strong Th1 and weak Th17 responses to TMEV infection. However, B6 mice receiving LPS develop strong Th17 and reduced Th1 responses, and become susceptible to TMEV-induced demyelination [48]. Susceptible SJL mice develop strong Th17 and weak Th1 responses. Injection of SJL mice with anti-IL-17A antibodies prevents the development of TMEV-induced demyelinating disease [65].

\subsection{Role of Innate Immunity Associated with TMEV Infection}

\subsubsection{Critical Roles of Pattern Recognition Receptors (TLRs and MDA-5)}

Mouse microglia express mRNA for TLR1-9 [58]. In addition, TLR stimulation activates the expression of MHC class II and costimulatory molecules, enabling the microglia to efficiently activate $\mathrm{CD} 4^{+} \mathrm{T}$ cells [58]. Infection of many different glial cells (neurons, 
microglia, oligodendrocytes, and astrocytes) and professional antigen-presenting cells (macrophages, dendritic cells, and B cells) with TMEV activates the production of various cytokines via TLR2, 3, 4, and 7 [30,38,70-72]. TMEV contains a single RNA genome recognized by TLR7 and the dsRNA intermediate by TLR3, and consequently TMEV infection activates NF- $\mathrm{kB}, \mathrm{AP}-1$, and IRFs, resulting in the production of various cytokines. These signals lead to further activation of NF- $\mathrm{KB}$ and increased production of various inflammatory cytokines such as IL- $1 \beta$, IL- 6 , and IFN $\alpha / \beta$, which augment the development of the pathogenic Th17 cell type $[30,38,63,65,73]$. In addition, the melanoma differentiationassociated gene 5 (MDA5) also recognizes viral messages leading to the activation of $\mathrm{NF}-\mathrm{kB}$ and preferentially promotes the production of IFN $\alpha / \beta$ [74]. Interestingly, NF- $\mathrm{kB}$ signaling is necessary for viral replication and the expression of $\mathrm{Bcl}-2$ and $\mathrm{Bcl}-\mathrm{xL}$, which prevent TMEV-induced cellular apoptosis extending viral replication and cytokine production [61,75]. Activation of chemokine and cytokine genes by TMEV is largely independent of the IFN $\alpha \beta$ pathway and partly dependent on the dsRNA-dependent protein kinase (PKR) and MAP kinase pathways [73,76]. Interestingly, the activation of NF- $\mathrm{KB}$ is necessary for TMEV infection/replication [61] and, thus, the pattern recognition receptor-mediated cellular activation also serves as a mediator of viral persistence (Figure 2).

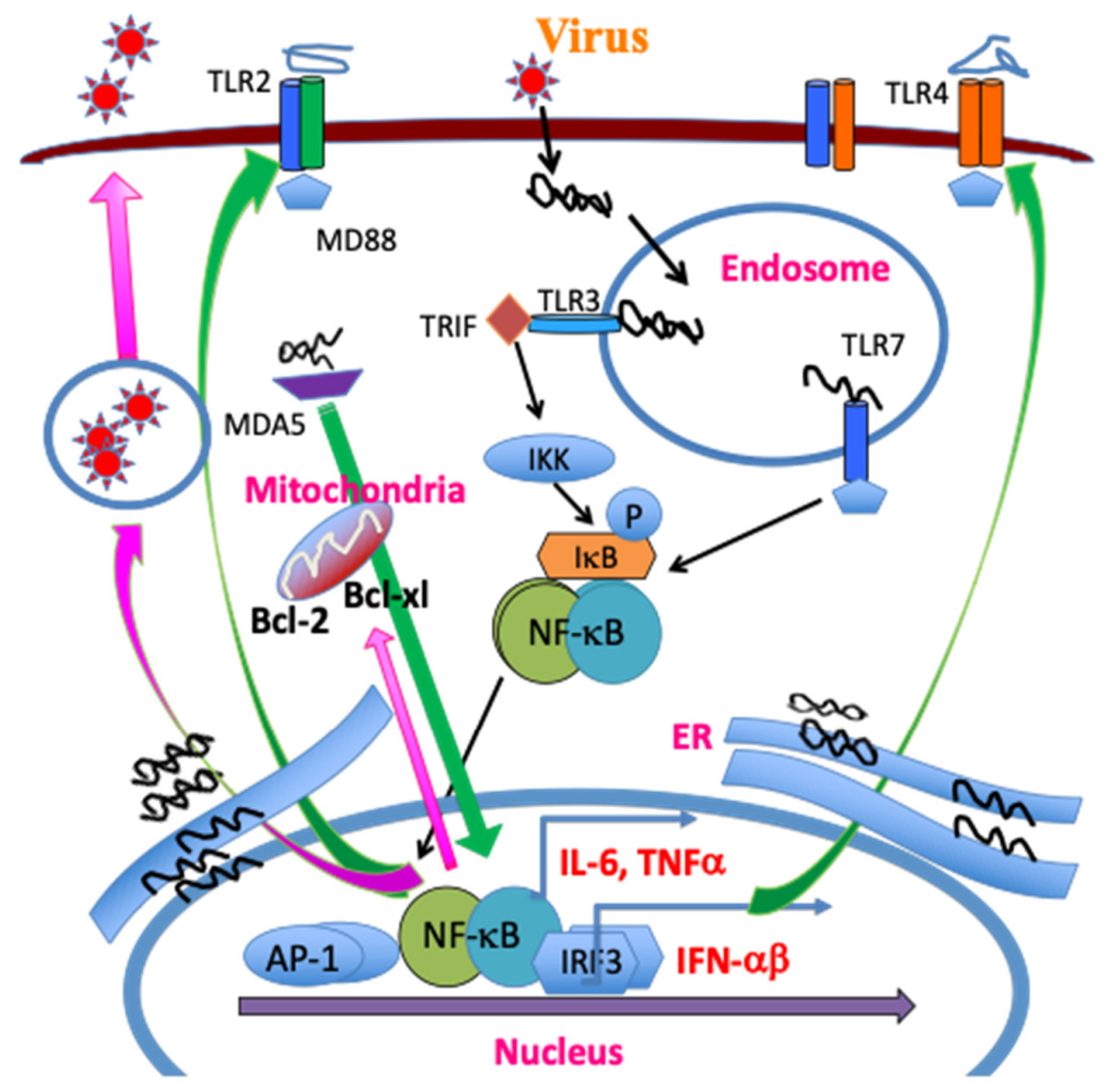

Figure 2. TMEV infection leads to release of a single stranded RNA genome and double stranded RNA replication intermediates in the endosome. The single RNA genome is recognized by TLR7, and the dsRNA intermediate, by TLR3. The TLR signaling activates NF- $\mathrm{KB}, \mathrm{AP}-1$ and IRFs, which in turn result in the production of various cytokines. MDA5 also recognizes viral messages leading to NF- $\mathrm{K} B$ activation. These activations lead to the additional expression and activation of TLR2/4, further activating NF- $\mathrm{kB}$. The amplified NF- $\mathrm{kB}$ signaling promotes TMEV replication and the expression of $\mathrm{Bcl}-2$ and $\mathrm{Bcl}-\mathrm{xL}$, which prevent virus-induced cellular apoptosis, increasing viral replication and cytokine production. 


\subsubsection{NLRP3 Inflammasome}

TLR-mediated signaling leads to the polymerization of the node-like receptor protein 3 (NLRP3) inflammasome, resulting in the activation of caspase- 1 and the subsequent production of IL-1 $\beta$ and IL-18 [77-79]. The MDA-5 signaling also promotes the activation of NLRP3 [80,81]. Consequently, TMEV infection induces strong NLRP3 inflammasome and downstream prostaglandin E2 $\left(\mathrm{PGE}_{2}\right)$ signaling in dendritic cells (DCs) and macrophages/microglia from susceptible SJL mice compared to the cells from resistant B6 mice [82]. Inhibition of $\mathrm{PGE}_{2}$ signaling using $\mathrm{AH} 23848$, an inhibitor of $\mathrm{PGE}_{2}$ receptor, decreases pathogenesis of TMEV-IDD and viral loads in the CNS, indicating the pathogenic role of $\mathrm{PGE}_{2}$ [82]. Furthermore, administration of IL- $1 \beta$ renders resistant B6 mice permissive to the development of TMEV-IDD, consistent with that the NLRP3 activation plays an important role in the pathogenesis $[48,82]$. The presence of a high IL- $1 \beta$ level elevates the pathogenesis by preferentially promoting the development of pathogenic Th17 responses [83]. These results suggest that the NLRP3 inflammasome signaling contributes to the pathogenesis of TMEV-induced demyelinating disease (Figure 2).

\subsubsection{Initial Chemokines and Cytokines}

Viral and bacterial infections result in the production of chemokines and cytokines, which further activate additional cytokine and chemokine gene expression, promoting cellular infiltration and subsequent induction of adaptive immune responses [84-86]. Various chemokines and cytokines are produced in the CNS of mice after viral infections, including TMEV [87-92]. TMEV infection upregulates various chemokine gene expressions in glial cells and other antigen-presenting cells as early as $1-3 \mathrm{~h}$ after infection [51,93]. The infection of primary glial cells, including astrocytes and microglia, results in the activation of chemokine genes (CXCL1, CXCL2, CXCL10, CCL2, CCL3, CCL4, CCL5, CCL7, and CCL12) that are important in the initiation of an inflammatory response [93-95]. These results suggest that glial cells play critical roles in the development of, or protection from, TMEV-induced, immune-mediated inflammatory disease. Treatment with anti-CCL2 antibodies results in a significant decrease in the clinical disease progression, decreased CNS inflammation, and reduced viral load in the CNS [96]. This study suggests a protective role of CCL2 in the development of TMEV-IDD. In contrast to CCL2, both the lack of CXCL1 during TMEV infection and the excessive presence of this chemokine promote the pathogenesis of demyelinating disease. Therefore, a balance in the level of CXCL1 during TMEV infection is critically important in controlling the pathogenesis of demyelinating disease, although the level of CXCL1 produced is significantly higher in cells from susceptible SJL mice compared to that in cells from resistant BALB/c or B6 mice [95,97].

Proinflammatory cytokines, such as IL- $1 \beta, \operatorname{IL}-6, \operatorname{IFN} \alpha / \beta$, and $\operatorname{TNF} \alpha$, produced upon TMEV infection via TLR-mediated signals, further upregulate the production of chemokines $[67,70,73,98]$. In addition, TMEV infection upregulates the production of fibrin deposition, different adhesion molecules such as ICAM and VCAM, and endothelin-1 associated with blood-brain barrier permeability and cellular infiltration, which appear to participate in the pathogenesis of demyelinating disease [56,99-102]. TNF- $\alpha$ also appears to play an important pathogenic role in the development of TMEV-IDD because higher numbers of TNF- $\alpha$ producing cells are found in TMEV-infected susceptible mice [103]. However, TNF- $\alpha$ may also play a protective role because the absence of TNF- $\alpha$ worsens the pathology in TMEV-infected mice [104]. The signaling by NLRP3 inflammasome leads to the production of IL-1 $\beta$ and PEG $_{2}$ [105]. TMEV infection activates NLRP3 via TLR signaling [82]. IL-1 and other inflammatory cytokines produced after TMEV infection are greater in susceptible mice compared to resistant mice [67]. A high IL-1 level plays a pathogenic role by elevating pathogenic Th17 responses, whereas a lack of IL-1 signals promotes viral persistence in the spinal cord due to insufficient $\mathrm{T}$ cell activation by elevating the production of inhibitory cytokines and regulatory molecules $[48,83]$. The inhibition of virus-induced $\mathrm{PGE}_{2}$ signaling results in decreased pathogenesis for TMEV-IDD, suggesting that the excessive activation of the NLRP3 inflammasome leading to the $\mathrm{PGE}_{2}$ signaling 
contributes to the pathogenesis [82]. The excessive $\mathrm{PEG}_{2}$ levels may prevent the $\mathrm{T}$ cell killing of target cells by inhibiting CD95L expression [106] and type I INF production [82]. TMEV infection upregulates the expression of PD- 1 and PDL-1 in the CNS via type I IFN signaling in conjunction with the presence of IL-6 signaling $[107,108]$.

TMEV infection results in the production of relatively high levels of Type I IFNs in various cell types from susceptible mice $[73,109,110]$. Type I IFNs stimulate T cell responses after TMEV infection by activating the expression of costimulatory molecules on APCs [30,63,111-113]. IFN-IR KO mice develop rapid fatal encephalitis accompanied with greater viral load and infiltration of immune cells of the CNS compared to the wild type mice [113]. The less efficient stimulation of virus-specific T cells in IFN-IR KO mice is attributable to the poor expression of costimulatory molecules on APCs. However, IFN-I also controls cellular infiltration to the CNS and shapes local T cell immune responses and $\mathrm{B}$ cell activation $[30,63,113]$. SJL DCs infected with TMEV induce rapid production of several different Type I IFNs (IFN- $\alpha 1$, IFN- $\alpha 2$, IFN- $\alpha 4$, IFN- $\alpha 5$, IFN- $\alpha 6$, IFN- $\alpha 7$, IFN- $\alpha 9$, IFN- $\alpha 11$, IFN- $\alpha \beta$, and IFN- $\beta$ ), and a type II IFN (IFN- $\gamma$ ) [63]. TMEV-infected DCs from susceptible mice produce higher levels of type I IFNs and IFN- $\gamma$ compared to virus-infected DCs from resistant mice. The difference in the production of IFNs contributes to the significantly different virus-induced apoptosis, inhibition of development, and function of DCs [63]. The antiviral effect of Type I IFNs on TMEV replication is rather narrowly limited to just before viral infection. Therefore, the presence of high levels of Type IFNs in susceptible SJL mice may not necessarily be beneficial in controlling viral loads in the TMEV-induced demyelinating disease.

IL-6 and IL-1 $\beta$ play particularly important roles in the pathogenic T cell responses in the development of TMEV-induced demyelinating disease $[65,83,113]$. In addition, the IL-1 $\beta$ signal amplifies IL-6 production and activates CD4 ${ }^{+} T$ cell expansion $[48,114]$. IL-6 participates in initiating and amplifying the pathogenesis of TMEV-induced demyelinating disease. In fact, mice lacking IL-6 signaling fail to develop demyelinating disease following TMEV infection $[65,75]$. However, the effect of IL- 6 could be different depending on the TMEV strains because SJL mice receiving IL-6 prior to TMEV DA infection are free from the disease [115]. In addition, the presence of IL-6 is essential for the survival of mice infected with other viruses, such as influenza virus or lymphocyte choriomeningitis virus $[116,117]$.

\section{Role of Virus-Specific Adaptive Immunity in TMEV-Induced Demyelination}

\section{1. $\mathrm{CD}^{+} \mathrm{T}$ Cells}

\subsubsection{Early Studies of $\mathrm{CD}^{+}{ }^{+} \mathrm{T}$ Responses}

The demyelination induced after TMEV-inoculation is immune-mediated based on early study results indicating that the treatment of mice with anti-thymocyte, anti-Ia (MHC class II), or anti-CD4 antibodies delays the onset of disease [118-120], and that the level of the delayedtype hypersensitivity response specific for viral antigens correlates with the course of clinical signs of disease [27]. During chronic TMEV infection, susceptible mice display prolonged T cell immune responses toward viral antigens $[13,121,122]$. The association between susceptibility to TMEV-induced demyelinating disease (TMEV-IDD) and the MHC [34,121], in addition to the T cell receptor (TCR) $\beta$-chain genes $[123,124]$, further supports involvement of $T$ cell responses in the pathogenesis. Moreover, many studies have suggested that the $\mathrm{CD} 4^{+} \mathrm{Th}$ response is pathogenic in susceptible mice [125-127]. Alternatively, some studies indicate that $\mathrm{CD}^{+} \mathrm{T}$ cells confer protection from disease [128-130]. However, these early studies potentially include different $\mathrm{CD} 4^{+} \mathrm{T}$ cell subpopulations, including Th1, Th17, and Treg cells, which are functionally different. I- $\mathrm{A}^{\mathrm{s}}$ restricted $\mathrm{CD} 4^{+} \mathrm{T}$ cell epitopes of TMEV in susceptible SJL mice have been identified: one major $\left(\mathrm{VP} 2_{72-86}\right)$ and two minor ( $\mathrm{VP}_{233-244}$, $\left.\mathrm{VP}_{24-37}\right)$ epitopes on capsid proteins and one predominant epitope $\left(3 \mathrm{D}_{21-36}\right)$ on RNA polymerase [126,131-133]. Similarly, two predominant $I-A^{b}$-restricted epitopes in resistant $\mathrm{B} 6$ mice have been found in the capsid region [134]. A diagram displaying the $\mathrm{CD}^{+} \mathrm{T}$ cell $\left(\mathrm{I}-\mathrm{A}^{\mathrm{s}}\right.$ and $\left.\mathrm{I}-\mathrm{A}^{\mathrm{b}}\right)$ and $\mathrm{CD} 8^{+} \mathrm{T}$ cell epitopes $\left(\mathrm{H}-2 \mathrm{~K}^{\mathrm{s}}\right.$ and $\left.\mathrm{H}-2 \mathrm{D}^{\mathrm{b}}\right)$ of TMEV BeAn is shown in Figure 3. 


\section{B6 epitopes}

\section{T cell epitopes of TMEV BeAn}

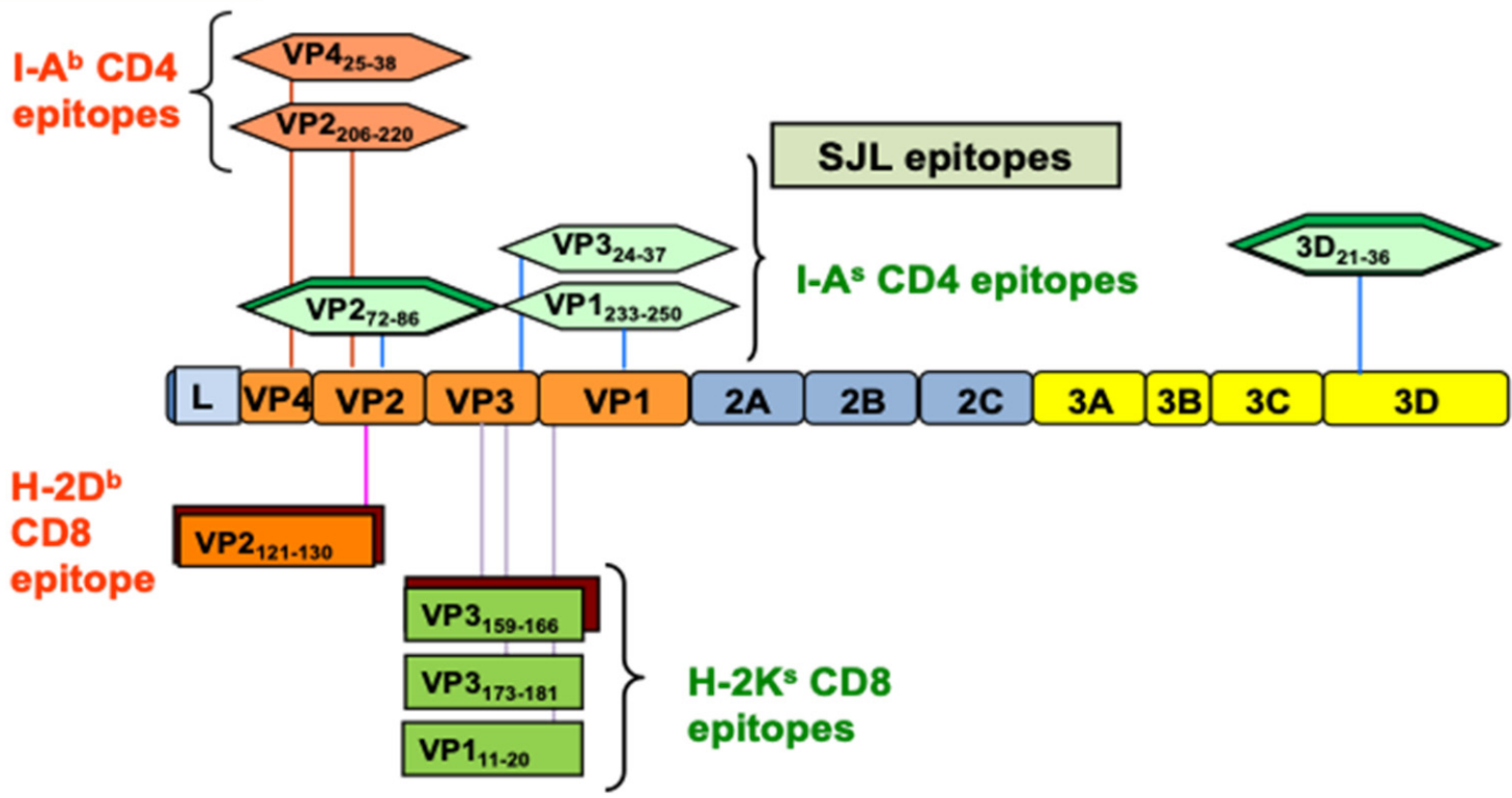

Figure 3. $\mathrm{CD}^{+}$and $\mathrm{CD} 8^{+} \mathrm{T}$ cell epitopes of the BeAn strain of TMEV restricted with $\mathrm{MHC} \mathrm{H-2}$ and $\mathrm{H}-2^{\mathrm{s}}$ haplotypes. The predominant epitopes are indicated by double boxes. One predominant H-2D $\mathrm{D}^{\mathrm{b}}$-restricted CD8 T cell epitope [135] and one predominant and two subdominant epitopes were found to be restricted with $\mathrm{H}-2 \mathrm{~K}^{\mathrm{s}}$ [35].

\subsubsection{Utilization of Virus-Specific $\mathrm{CD} 4^{+} \mathrm{T}$ Cell Receptor Transgenic Mice}

As $\mathrm{CD}^{+} \mathrm{T}$ cells include several subpopulations (Th1, Th17, and Treg), which have distinct functions in the development of antiviral immunity and inflammatory diseases, the availability of naïve undifferentiated virus-specific $\mathrm{CD} 4^{+} \mathrm{T}$ cells is critically important for investigating $\mathrm{CD}^{+} \mathrm{T}$ cell differentiation during TMEV infection. TCR transgenic mice specific for a major $\mathrm{CD}^{+} \mathrm{T}$ cell epitope (VP2 ${ }_{72-86}$ ) of TMEV restricted with I-A ${ }^{\mathrm{s}}$ (018030, SJL.Cg-Tg (TcraTcrbVP2) 1 Bkim/J from the Jackson Laboratory) have been used to investigate the differentiation of $\mathrm{CD}^{+} \mathrm{T}$ cell types during viral infection $[65,136]$. CD4 $4^{+}$

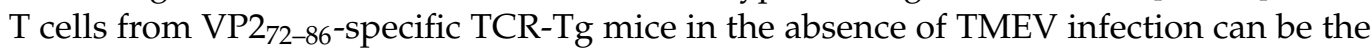
source of naïve $\mathrm{CD} 4^{+} \mathrm{T}$ cells and the $\mathrm{T}$ cell differentiation could be investigated in the presence of virus-infected APCs (Figure 4). The differentiation of $\mathrm{CD}^{+} \mathrm{T}$ cell types were investigated by comparing T cell development in TMEV-infected TCR-Tg mice with those infected with UV-inactivated TMEV. The differentiation was also investigated following the adoptive transfer of CFSE-labeled naïve VP2 TCR-Tg CD4 ${ }^{+} \mathrm{T}$ cells into SJL mice followed by TMEV infection [136]. Alternatively, the differentiation of naïve TCR-Tg CD4 ${ }^{+} \mathrm{T}$ cells has been investigated in vitro in the presence of TMEV-infected DCs or UV-inactivated TMEV-infected DCs [65]. 

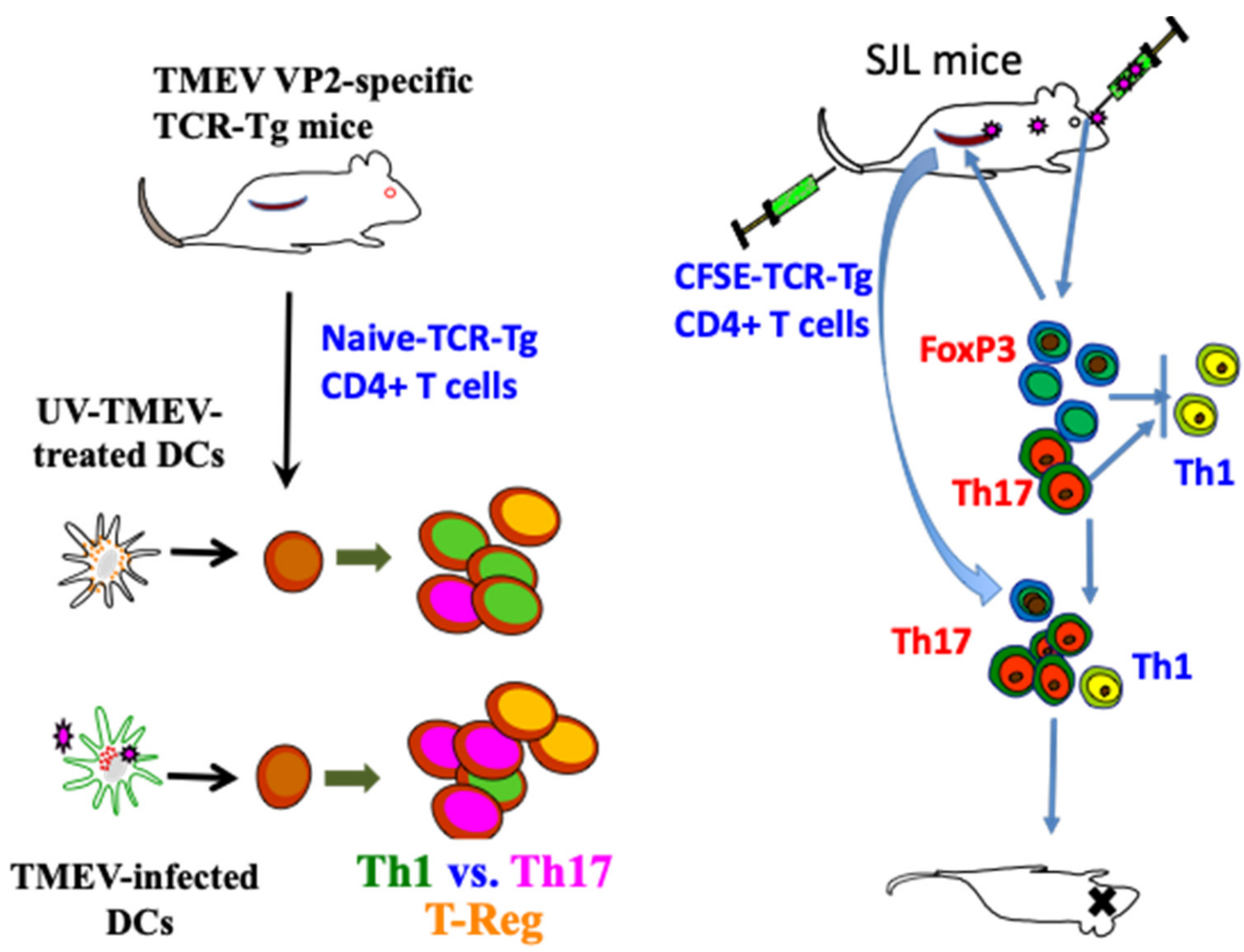

Figure 4. Utilization of TMEV VP2 $72-86^{-s p e c i f i c ~ T C R-T g ~ m i c e ~ i n ~ a n a l y z i n g ~ t h e ~ d e v e l o p m e n t ~ o f ~ C D 4 ~}{ }^{+}$T cell subpopulations during TMEV infection $[65,136]$. These signals induce the production of IL-1, IL-6, IFN $\alpha / \beta$, and TGF- $\beta$, which promote elevated induction of pathogenic FoxP3 ${ }^{+}$T-reg, Th17, and Tc17. Furthermore, IL-6 and IL-17, in addition to Tim and PDL-1, synergistically inhibit protective CD8 ${ }^{+} \mathrm{T}$ lymphocytes (CTL) function [107]. IFN $\alpha / \beta$ inhibits Th1 responses and elevates the expression of costimulatory molecules on antigen-presenting cells (APCs), which in turn promotes the induction of Th17 responses $[63,113]$.

\subsubsection{Involvement of Th1 Cells}

TMEV-specific Th1 cells producing IFN- $\gamma$ mediate lysis of the virus-infected glial cells in a Fas-dependent mechanism [137]. Preimmunization of SJL mice with capsid-epitope peptides significantly increased capsid-specific $\mathrm{CD}^{+} \mathrm{T}$ cell numbers in the CNS during the early stages of viral infection [138]. These preimmunized mice delay the development of demyelinating disease in SJL mice, suggesting a protective role of capsid-reactive Th1 cells. Genetically resistant mice with deficiencies in the IFN- $\gamma$ or its receptor genes fail to clear TMEV and develop extensive demyelinating disease $[139,140]$. Similarly, the intraperitoneal (i.p.) injection of susceptible mice with an IFN- $\gamma$-neutralizing monoclonal antibody $(\mathrm{mAb})$ or of mice deficient in the Type I IFN receptor significantly accelerates the onset of disease [112,141,142]. The treatment of mice with anti-IFN- $\gamma$ mAb does not reduce the delayed-type hypersensitivity (DTH) response to the virus and does not produce significant effects in the clinical course of disease, suggesting that DTH response may not reflect their Th1 response [141]. However, intracerebral administration of recombinant IFN- $\gamma$ significantly accelerates the onset of TMEV-induced disease and the enhancing effect of IFN- $\gamma$ is abrogated with treatment with anti-IFN- $\gamma$ mAb [141]. Therefore, the level of IFN- $\gamma$ appears to play a key role in the TMEV-induced inflammatory response and the perturbation of this cytokine may alter the course of demyelinating disease. IFN- $\gamma$ is produced by natural killer (NK) cells, and $\mathrm{CD}^{+}$and $\mathrm{CD} 8^{+} \mathrm{T}$ cells, and thus, the effect of IFN- $\gamma$ may not entirely reflect the function of the $\mathrm{CD} 4^{+} \mathrm{T}$ cell population. In addition, the presence of IFN- $\gamma$ receptors on the CNS glia suggests the importance of the target 
cells in the function of IFN- $\gamma$ during TMEV-induced demyelination [143]. The effects of preimmunization and tolerization with individual epitopes indicate that capsid-specific $\mathrm{CD} 4^{+} \mathrm{T}$ cells are protective, whereas viral RNA polymerase $\left(3 \mathrm{D}_{21-36}\right)$-specific $\mathrm{CD} 4^{+} \mathrm{T}$ cells exacerbate the development of TMEV-induced demyelinating disease [133]. These results suggest the location and abundance of Th1 responses also play a role in the protection from the pathogenesis of TMEV-induced demyelinating disease.

\subsubsection{Role of Th17 Cells}

Th17 cells producing IL-17, which are a distinct subset of CD4 $4_{+} \mathrm{T}$ cells, are involved in the pathogenesis of various autoimmune diseases [144-147]. Th17 cells preferentially develop in an IL-6-dependent manner after TMEV infection [65,75]. The presence of IL-6 is necessary for the development of Th17 responses and the pathogenesis of TMEV-IDD as shown with IL-6 KO mice [75]. Th17 cells promote the pathogenesis of chronic demyelinating disease by increasing viral persistence via upregulating antiapoptotic molecules and blocking target cell killing by cytotoxic T cells. Administration of the neutralizing antibody against IL-17 augments viral clearance and prevents the pathogenesis of TMEVinduced demyelinating disease [65]. The presence of IL-6 further synergistically enhances the antiapoptotic function of IL-17 function, which further facilitates the TMEV persistence in the CNS [75]. Conversely, IL-17 may also further induce IL-6, which amplifies the IL-17/IL-6 cytokine circuit [148]. The association of Th17 responses to the pathogenesis of TMEV-induced demyelinating disease has been confirmed using Th17-biased ROR $\gamma \mathrm{t} \mathrm{Tg}$ mice with the B6 background, which render the development of TMEV-IDD with elevated Th17 responses, in contrast to the control B6 mice [149]. Using isolated DCs infected with live TMEV and UV-inactivated TMEV, it has been demonstrated that the development of Th17 cells is dependent on DCs infected with live TMEV producing various innate immune responses [65]. Thus, these results indicate a pathogenic role of Th17 cells in persistent TMEV infection and the pathogenesis of associated chronic inflammatory demyelinating diseases (Figure 4).

\subsubsection{Participation of FoxP3 ${ }^{+}$Regulatory T Cells}

High levels of FoxP3+CD4+ T cells are present in the CNS of virus-infected mice as early as $3 \mathrm{~d}$ after viral infection $[150,151]$. The early induction of $\mathrm{FoxP}^{+} \mathrm{CD}^{+} \mathrm{T}$ cells may depend on the function of the TCR2-mediated signal $[152,153]$ upregulated after TMEV infection [72]. When FoxP3 ${ }^{+} \mathrm{CD}^{+} \mathrm{T}$ cells were removed, viral loads in the CNS and the development of clinical signs were significantly reduced in susceptible SJL mice [150], but not in resistant C57BL/6 mice [154]. These results suggest that the presence of a high level of $\mathrm{FoxP}^{+} \mathrm{CD}^{+} \mathrm{T}$ cells promotes the pathogenesis of demyelinating disease. However, as much as a two-fold higher proportion of $\mathrm{FoxP}^{+} \mathrm{CD}^{+} \mathrm{T}$ cells in the CNS of virus-infected SJL mice displaced CD25 ${ }^{10}$ [136]. Thus, FoxP3 ${ }^{+} \mathrm{CD} 4^{+} \mathrm{T}$ cells in the CNS may require further activation to be functional regulatory $T$ cells [155-157]. High levels of $\mathrm{CD}^{-} 5^{-} \mathrm{FoxP}^{+} \mathrm{CD}^{+} \mathrm{T}$ cells were also observed in chronic hepatitis $\mathrm{B}$ virus-infected patients [158] and patients with systemic lupus [159]. CD25 $5^{\mathrm{lo}} \mathrm{FoxP} 3^{+} \mathrm{CD}^{+} \mathrm{T}$ cells may lose FoxP3 expression and undergo trans-differentiation into pathogenic Th17 cells $[160,161]$. Therefore, it is conceivable that some or most of the $\mathrm{CD} 25^{\mathrm{lo}} \mathrm{FoxP} 3^{+} \mathrm{CD} 4^{+} \mathrm{T}$ cells may be converted into pathogenic Th17 cells under the environment of abundant cytokines such as IL- 6 and IL- $1 \beta$ in the CNS of TMEV-infected mice $[65,83,136]$.

In many chronic viral infections, including TMEV, FoxP3 ${ }^{+} \mathrm{CD}^{+} \mathrm{T}$ cells appear to contribute to the pathogenesis by inhibiting protective $\mathrm{T}$ cell function and consequently promoting viral persistence $[150,162]$. In contrast, $\mathrm{FoxP}^{+} \mathrm{CD}^{+} \mathrm{T}$ cells may be beneficial in controlling acute viral infections $[163,164]$. CD2 $5^{\text {lo }} \mathrm{FoxP}^{+} \mathrm{CD}^{+} \mathrm{T}$ cells do not appear to display regulatory function [157]. After activation of $\mathrm{CD} 25^{\text {lo }} \mathrm{FoxP} 3^{+} \mathrm{CD} 4^{+} \mathrm{T}$ cells in vitro under experimental conditions with various cytokines and peptides [156,165,166], up to $60 \%$ of $\mathrm{CD}^{+} \mathrm{T}$ cells bear FoxP3 and CD25 hi [136]. The TMEV VP2-specific FoxP3 ${ }^{+} \mathrm{CD}^{+}$ $\mathrm{T}$ cells activated in vitro inhibit the production of IFN- $\gamma$ but not IL-17 by VP2-specific 
$\mathrm{CD}^{+} \mathrm{T}$ cells [136]. In contrast, activated epitope-specific FoxP3 ${ }^{+} \mathrm{CD} 4^{+} \mathrm{T}$ cells in MHVinfected mice efficiently inhibit the proliferation of the same epitope-specific CD4 ${ }^{+} \mathrm{T}$ cells [151]. The previous studies indicating the inhibition of proliferation of Th cells utilized FoxP3 ${ }^{+} \mathrm{CD}^{+} \mathrm{T}$ cells generated in vivo from TMEV-infected mice [150]. In addition, MHV-specific FoxP3 ${ }^{+} \mathrm{CD}^{+}{ }^{+}$cells were stimulated in vitro with anti-CD3 and anti-CD28 antibodies instead of using the epitope peptide [151]. Therefore, activating antigens for $\mathrm{FoxP}^{+} \mathrm{CD}^{+} \mathrm{T}$ cells and Th cells, in addition to the heterogeneity of target Th cells during the inhibition assays, may be important. TMEV-infected mice treated with ex vivo-generated FoxP3 ${ }^{+}$Tregs at an early stage of viral infection worsened the clinical signs, whereas the mice treated with the Tregs at a later stage decreased immune cell recruitment in the CNS [167]. Nevertheless, VP2 epitope-specific FoxP3 ${ }^{+} \mathrm{CD}^{+} \mathrm{T}$ cells preferentially inhibited the production of IFN- $\gamma$, but not IL-17, by the same epitope-reactive Th cells [136]. As virus-reactive IFN- $\gamma$-producing Th1 cells are protective but IL-17-producing Th17 cells inhibit Th1 development and cytotoxic $\mathrm{T}$ cell function $[65,168]$, FoxP3 ${ }^{+} \mathrm{CD} 4^{+} \mathrm{T}$ cells together with Th17 cells may promote the pathogenesis of TMEV-induced demyelinating disease in an epitope-dependent manner (Figure 5).

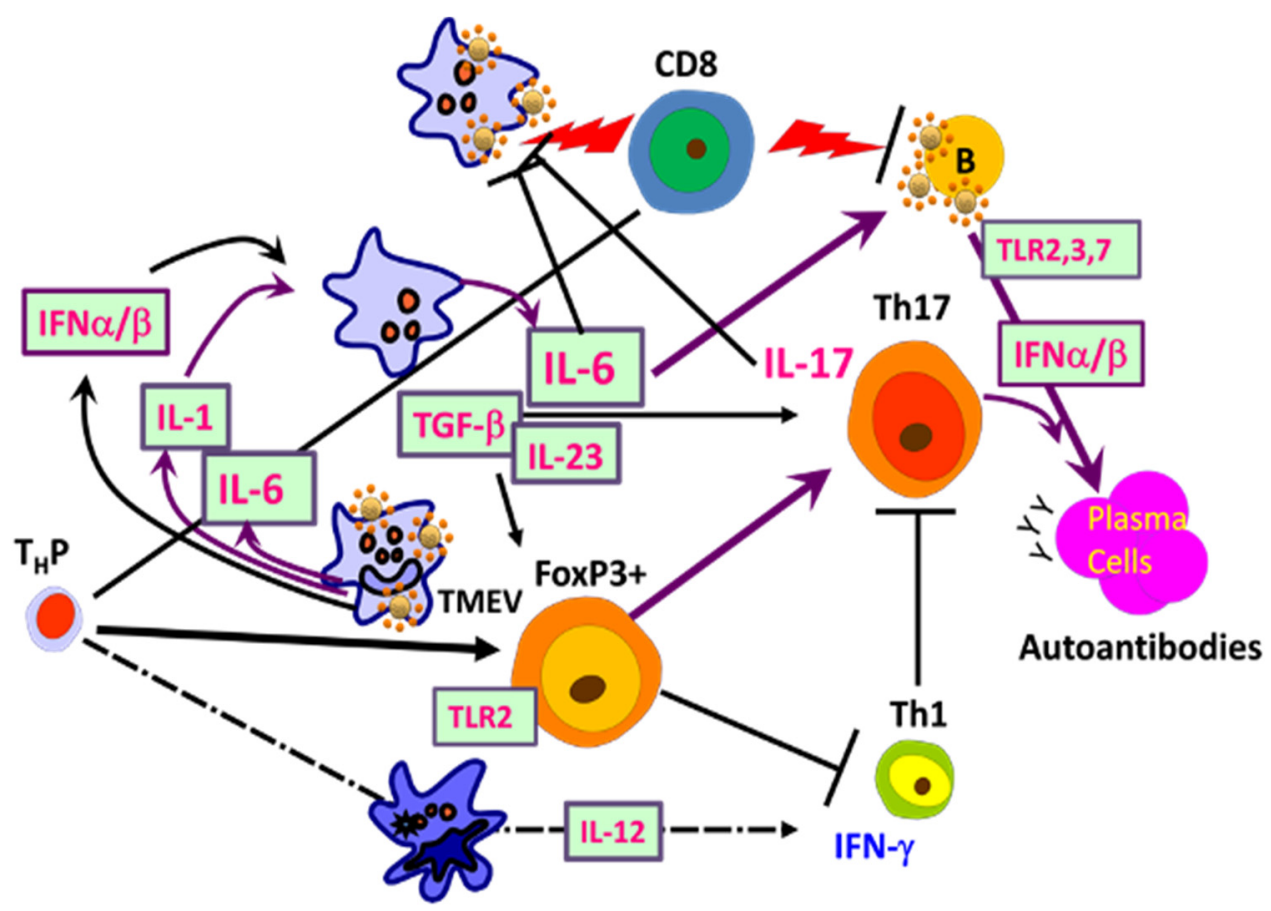

Figure 5. Interactions of adaptive immune responses to TMEV and autoantigens in susceptible mice. Infection of susceptible mice with neurotropic TMEV induces excessive levels of innate immune cytokines, including type I IFNs, IL-6, and IL-1, which promote inflammatory Th17 responses from FoxP3 $^{+}$T-reg cells over protective Th1 responses, leading to high viral loads in the CNS. Various glias and antigen-presenting cells (APCs), including B cells, are permissive to the viral infection and participate in the innate immune responses. FoxP3 ${ }^{+} \mathrm{T}$ cells and Th17 cells are involved in the inhibition of protective $\mathrm{CD} 8^{+} \mathrm{T}$ cell function, which further elevates the viral persistence and pathogenesis of demyelination. B cells are also activated and stimulated to produce elevated levels of antibodies. Such high viral loads and innate cytokines, in addition to adaptive immune responses in the CNS, lead to CNS tissue damage releasing sequestered autoantigens.

\subsection{Roles of $C D 8^{+} T$ Cells in the Pathogenesis of TMEV-IDD}

\subsubsection{Role of Tc1}

As demyelination is closely linked to viral persistence [42-44], TMEV-specific cytotoxic $\mathrm{CD}^{+} \mathrm{T}$ cells producing IFN- $\gamma$ and perforin (Tc1) are likely to play an important role in protection and/or resistance $[39,169,170]$. TMEV-specific cytotoxic CD8 ${ }^{+} \mathrm{T}$ lymphocytes 
(CTL) appear to damage virus-infected, myelin-producing oligodendrocytes and other cell types [171-174]. Many investigations further confirmed the role of Tc1 cells by antibodymediated $\mathrm{CD}^{+} \mathrm{T}$ cell depletion [175], and using Class I deficient mice [176-178]. Rodriguez and his colleagues proposed that $\mathrm{CD} 8^{+} \mathrm{T}$ cells are necessary for the manifestation of clinical symptoms using the DA strain of TMEV $[169,173]$. However, $\beta_{2} \mathrm{M}$-deficient or perforin-deficient mice on a resistant background are susceptible to both demyelination and clinical disease [170,176-178]. Furthermore, $\beta_{2} \mathrm{M}$-deficient mice with the susceptible SJL background displayed similar exacerbation of TMEV-IDD [179]. These results indicated a protective role of $\mathrm{CD}^{+} \mathrm{T}$ cells in the development of TMEV-induced demyelinating disease in both resistant and susceptible mice. Moreover, the presence of a high level of CTL in resistant mice and a low level in susceptible mice [180], and the resistance to TMEV-IDD in susceptible mice adoptively received CD8 ${ }^{+} \mathrm{T}$ cells [181], further support the protective function of CTL. In resistant B6 mice, the majority ( $50 \%$ to $70 \%$ ) of CNSinfiltrating CD8 ${ }^{+} \mathrm{T}$ cells recognize VP2 ${ }_{121-130}[182,183]$, and two minor populations $(<10 \%)$ react with VP2 $165-173$ and VP3 ${ }_{110-120}$ capsid epitopes [184] based on the production of IFN- $\gamma$ (Figure 3). Similarly, CNS-infiltrating CD8 ${ }^{+}$T cells of virus-infected SJL mice react with one predominant (VP3 $159-166$, ) and two subdominant capsid epitopes (VP3 $173-181$, and $\mathrm{VP}_{11-20}$ ) [35]. During the early stages of viral infection, a lower level of virus-specific $\mathrm{CD}^{+} \mathrm{T}$ cells in SJL mice was observed [184]. In addition, the resistance of (B6xSJL)F1 mice is associated with a higher level of the initial virus-specific $\mathrm{H}-2 \mathrm{~b}$-restricted $\mathrm{CD} 8^{+} \mathrm{T}$ cell responses compared to the $\mathrm{H}-2 \mathrm{~s}$-restricted $\mathrm{CD} 8^{+} \mathrm{T}$ cell responses [37]. These results further suggest that Tc1 cells play an important protective role in preventing TMEVIDD by clearing viral loads from the CNS. There is, however, a possibility that certain $\mathrm{CD}^{+} \mathrm{T}$ cell populations play a pathogenic role, perhaps depending on epitope-reactivity or cytokine production, in TMEV-induced demyelination [171-173,185]. Similar CTLmediated immunopathology was reported with the lymphochoriomeningitis virus (LCMV) and Coxsackie B virus in mice [186-188].

\subsubsection{Role of Tc17}

Chronic inflammation promotes the induction of IL-17-producing CD8 ${ }^{+}$cells with reduced cytolytic function $[189,190]$. Therefore, it is conceivable that a subset of CD8 ${ }^{+} \mathrm{T}$ cells producing IL-17 may be associated with the pathogenesis of TMEV-IDD. To investigate the possible epitope-dependent function of $\mathrm{CD}^{+} \mathrm{T}$ cells in the protection and/or pathogenesis, a single amino acid substitution was introduced into the predominant viral epitope (VP3 $3_{159-166}$ ) and / or a subdominant viral epitope (VP3 $\left.{ }_{173-181}\right)$ of susceptible SJL/J mice by site-directed mutagenesis altering a single amino acid within the epitopes [191]. The resulting variant viruses (substituted at N160V, P179A, and N160V/P179A) failed to induce CD8 ${ }^{+} \mathrm{T}$ cell responses in the respective epitopes. TMEV (N160V and N160V/P179A) viruses, deficient in the predominant $\mathrm{CD} 8^{+} \mathrm{T}$ cell epitope, do not induce demyelinating disease [191]. The $\mathrm{CD}^{+} \mathrm{T}$ cells specific for the predominant $\mathrm{VP} 3_{159-166}$ epitope identified by reactivity with the tetramers containing VP3 ${ }_{159-166}$ showed strong cytolytic activity and produced high levels of IFN- $\gamma$. In contrast, VP3 $173-181^{-}$-specific $\mathrm{CD} 8^{+} \mathrm{T}$ cells produced higher levels of transforming growth factor beta, interleukin-22 (IL-22), and IL-17 mRNA, and exhibited minimal cytotoxicity. Therefore, it is conceivable that differences in the functional avidity toward their cognate epitopes and/or the type of cytokines produced may affect the function of $\mathrm{CD} 8^{+} \mathrm{T}$ cell populations in an epitope-dependent manner. IFN- $\gamma$ producing $\mathrm{VP}_{159-166^{-}}$-specific CD8 ${ }^{+}$ $\mathrm{T}$ cells with high cytolytic function, in contrast to low-cytolytic VP3 $173-181^{-s p e c i f i c ~ C D 8^{+}} \mathrm{T}$ cells, may be necessary to initiate the pathogenic process by destroying infected neurons and/or releasing sequestered autoantigens followed by Tc-17- and Th17-mediated inhibition of cytolytic function promoting viral persistence. Thus, both Th17 and Tc1 populations reactive to TMEV epitopes may cooperatively participate in the pathogenesis of virally induced demyelinating disease in an epitope-dependent manner [191]. 


\subsection{Role of B Cells in the Development of TMEV-IDD \\ 3.3.1. Anti-TMEV Antibody Responses}

The major neutralizing antibody epitopes of TMEV reside on VP1, and these epitopes may also be involved in virus-binding to cellular receptors [192,193]. The antibodies found in the spinal fluids of TMEV-infected mice [194] and in MS patients [195] displayed relatively limited heterogeneity. Furthermore, B cells producing antibodies to VP1 and VP2 proteins are detectable in the demyelinating lesions [196]. The plasma cells producing anti-TMEV antibodies were found primarily in perivascular infiltrates and in the meninges of the CNS parenchyma [197].

Antibodies from TMEV-infected mice also recognize several linear epitopes of 13-15 amino acid peptides or recombinant proteins representing the capsid proteins, and some of these antibodies display varying degrees of virus neutralization accompanying the protection from demyelinating disease development [122,198-200]. Anti-TMEV antibody responses during the early stage of viral infection play a protective role $[49,201,202]$. In addition, treatment of mice with the monoclonal anti-CD20 antibody accelerate the pathogenesis of TMEV-induced demyelinating disease, suggesting a protective role of the $\mathrm{B}$ cells [203]. However, antibodies to viral determinants appear to play a relatively minor role in the protection of mice from the pathogenesis of demyelinating disease compared to $\mathrm{CD}^{+}$Th1 and CD8 ${ }^{+} \mathrm{T}$ cells $[122,201,202]$.

\subsubsection{B Cells as a Viral Reservoir and Their Role in T Cell Activation}

An earlier study suggested that B cells are not permissive to TMEV infection [204]. However, a recent study showed as much as $40 \%$ of primary B cells in susceptible SJL mice are permissive to TMEV infection and replication [30]. TMEV-infected B cells expressed elevated levels of an activation marker, CD69. In addition, the expression of MHC class II and costimulatory molecules was upregulated in the infected B cells, accompanied by elevated levels of antigen-presenting function and antibody production [30]. The upregulation of these $B$ cell activation markers induced with TMEV infection was replicated with the treatment of B cells with TLR ligands for TLR2, TLR3, TLR4, TLR7, and TLR9, suggesting that $B$ cell activation after TMEV infection is associated with TLR signals [30]. These results are consistent with the previous findings that various TLR-mediated signals activate B cells to function as an important professional APC type involved in the activation of Th cell types [205-207]. The innate responses via TLRs following TMEV infection appear to trigger excessive production of IFN- $\alpha / \beta$, IL- 6 , IL- 1 , and PGE 2 in B cells of susceptible mice $[30,208-210]$. These innate immune responses following TMEV infection also activate $\mathrm{B}$ cells to produce antibodies and facilitate elevated $\mathrm{T}$ cell responses [30]. In addition, these cytokines may, in turn, further enhance the viral persistence by inhibiting apoptosis of TMEV-infected B cells and protective Th1 cell responses, while enhancing pathogenic Th17 responses [65,82] (Figure 5). Furthermore, TMEV-infected B cells form a germinal center-like structure with close proximity of $\mathrm{T}$ cells in the CNS, which may promote the induction of pathogenic $\mathrm{T}$ cells, such as Th17 and FoxP3 ${ }^{+}$Treg, recognizing not only viral determinants but also autoantigens [30].

\section{Development of Autoimmune Responses during TMEV-IDD}

Early studies indicated that antibody responses to self-antigens including myelin basic protein (MBP) in the CNS were induced during chronic infection with TMEV [28,30,211]. Similarly, Th cell responses to myelin-associated autoantigens in the CNS were also previously identified during chronic infection with TMEV [14]. In addition, TMEV-infected SJL mice displayed a $\mathrm{CD} 8^{+}$cytotoxic $\mathrm{T}$ cell population apparently recognizing both viral determinant and autoantigen capable of causing CNS degeneration [212]. Thus, chronic TMEV infection appears to induce various antibody, $\mathrm{CD} 4^{+} \mathrm{T}$ cell, and $\mathrm{CD} 8^{+} \mathrm{T}$ cell responses to CNS autoantigens. It has previously been proposed that the presence of molecular mimicry between viral determinants and autoantigens leads to the cross-reactive antibody and $\mathrm{T}$ cell responses following TMEV infection [213]. Alternatively, it is possible that 
sequestered autoantigens to the CNS may be released following TMEV-induced tissue damage and these released autoantigens induce such autoreactive antibody and $\mathrm{CD} 4^{+} \mathrm{T}$ cell responses $[30,214]$. However, rapidly accelerated production of the same autoantibodies was observed in systemic lupus erythematosus-prone mice, such as NZBWF1 and BXSB male mice, following infection with TMEV or Coxsackie virus [30]. These results strongly suggest that the autoimmune responses induced after TMEV infection reflect virus-induced TLR-mediated polyclonal activation of pre-existing autoimmune cells in a high frequency. In fact, ligands of various TLRs lead to the activation of B cells and T cells similar to TMEV infection [30]. The potential role of these autoimmune responses in the development of TMEV-induced demyelinating disease is not yet clear. As virus-reactive T cell responses are necessary to induce TMEV-induced demyelinating disease [49,55,65,191], the initial immune-mediated tissue damages of virus-infected cells may be a prerequisite for the pathogenesis of disease. Nevertheless, these autoimmune responses may participate in further damaging the related tissues and some may be involved in the protection, as previously suggested [215-217].

\section{Shaping Adaptive Immune Responses by Innate Immunity after TMEV Infection 5.1. Excessive Innate Immunity Initiates the Pathogenesis of TMEV-IDD}

The cytokine levels produced after TMEV infection are significantly greater in the glial cells and APCs of susceptible SJL mice than in those of resistant mice $[38,59,67]$. TLR-mediated signaling plays an important role in the induction of innate cytokine responses [30,70-72]. In particular, TMEV infection induces the high levels of IL-1 $\beta$, IL-6, $\operatorname{IFN} \alpha / \beta$, and TNF $\alpha$ via TLR-mediated signals in cells from susceptible mice compared to those from resistant mice $[67,70,73]$. Treatment of susceptible mice with poly IC, a ligand of TLR3, prior to TMEV infection exacerbates disease development, whereas this treatment after viral infection decreases the disease development [66]. Excessive levels of cytokines such as IL-6 and IL-1 $\beta$ produced via TLR3 signaling prior to viral infection hinder the induction of protective IFN- $\gamma$-producing $\mathrm{CD}^{+}$and $\mathrm{CD}^{+} \mathrm{T}$ cell populations. Treatment of resistant B6 mice with LPS, a ligand of TLR4, or IL-1 $\beta$, caused the mice to develop TMEV-induced demyelinating disease [48]. Similarly, susceptible SJL mice infected with a low pathogenic strain of TMEV developed a full-blown demyelinating disease after treatment with LPS [218]. Therefore, the excessive production of IL-6 and IL-1 $\beta$ appears to be mainly responsible for the development of demyelinating disease via preferential differentiation of pathogenic Th17 cells [65,83]. In addition, DCs treated with UV-inactivated TMEV predominantly induce protective Th1 responses in vitro, whereas DCs infected with live TMEV preferentially mount pathogenic Th17 responses [65]. The initial status of virus-specific $\mathrm{CD} 4+\mathrm{T}$ cell differentiation appears to play an important role in the pathogenesis of disease, because adoptive transfer of VP2-primed VP2-TCR-Tg CD4+ T cells into naive SJL mice, in contrast to the naïve T cells, provides protection from TMEV-induced demyelinating disease [136]. In addition, IL-6 and IL-17, which are the cytokines produced by Th17, synergistically promote the survival of virus-infected cells by preventing cellular apoptosis and CTL-mediated cytolysis [75]. Furthermore, upregulated production of IL-6 results in the expression of higher levels of PD-1 and PDL-1, which inhibit CTL function of $\mathrm{CD}^{+} \mathrm{T}$ cells [107]. In addition, poly IC-pretreated mice displayed elevated PDL-1 and regulatory FoxP3 ${ }^{+} \mathrm{CD}^{+} \mathrm{T}$ cells in the CNS, whereas poly IC-post-treated mice expressed reduced levels of PDL- 1 and FoxP3 ${ }^{+} \mathrm{CD}^{+}{ }^{+} \mathrm{T}$ cells $[66,107]$. A high level of IL-1 $\beta$, which amplifies IL-6 production [48,114], elevated pathogenic Th17 responses [83]. However, the lack of IL-1 signals promoted viral persistence due to insufficient $T$ cell activation [83]. Therefore, the timing and balance of IL-1 signaling must be important for the protection from TMEV-induced demyelinating disease.

\subsection{Viral Load and Persistence}

Both immune response and viral persistence in the CNS appear to play an important role in the pathogenesis of demyelination [45-48]. The level of anti-TMEV immunity, rather 
than the viral persistence level, is important for the pathogenesis of demyelinating disease, as shown with P1-transgenic mice (Table 1) which are immunologically tolerant to all of the capsid proteins of TMEV [49]. The P1 region of TMEV encodes the major CD4 ${ }^{+}$and the $\mathrm{CD} 8^{+} \mathrm{T}$ cell epitopes (Figure 3 ). Despite the drastically increased viral loads in the CNS, SJL P1-Tg mice developed significantly reduced antiviral immune responses and less severe demyelinating disease, suggesting that TMEV persistence is required but not sufficient to induce the disease [49]. Therefore, the level of pathogenic T-cell immunity to viral capsid epitopes clearly contributes to the development of demyelinating disease in SJL mice. These results are consistent with the contribution of certain CD8 ${ }^{+} \mathrm{T}$ cell and Th17 responses to the pathogenesis of TMEV-induced demyelination $[65,191]$.

The cellular activation status affects the levels of TMEV infection and/or replication, and the increased viral loads in turn elevate the level of inflammatory responses in a continued loop [61]. TMEV replication in infected cells is dependent on the activation of NF- $\mathrm{KB}$ and partially MAP kinase. In addition, treatment of macrophages with LPS, a strong inducer of innate cytokine responses, increases viral replication, and persistence in the CNS, leading to the pathogenesis of demyelination $[48,59,61,218]$. Several TLRs are associated with the production of inflammatory cytokines via activation of NF- $\mathrm{kB}$ following TMEV infection $[48,67,70,73,98]$. In addition, the activation of NF- $\mathrm{kB}$ is required for TMEV infection and replication [61]. Furthermore, the initial proinflammatory cytokines, such as TNF- $\alpha$, IL-6, and IL-1, produced in virus-infected cells may further activate NF- $\mathrm{KB}$ in adjacent cell populations to facilitate enhanced TMEV infection and replication (Figure 2). Due to the reduction of TLR-mediated signals by blocking TLR activation or NF-KB activation during viral infections, these signals are likely associated with the pathogenesis of demyelinating disease $[61,66,73,219]$. In addition, TMEV infections and replications are greater in cells of susceptible mice than in cells of resistant mice, and lead to the production of excessive cytokines and TLR signals promoting the pathogenesis of demyelinating disease $[67,70,73]$.

\subsection{Relevance of TMEV-IDD in Understanding Other Chronic Viral Inflammatory Diseases}

The significance of the TMEV system as an infectious model for MS is manifold. TMEV-induced demyelination $[9,10,13,14]$ serves as an excellent infectious model for the following reasons: (1) wildtype isolates from infected mice, without attenuation, result in chronic demyelinating disease; (2) chronic pathological involvement is limited to the white matter of the CNS; (3) myelin breakdown is directly related to the clinical symptoms such as gait spasticity and urinary incontinence; (4) demyelination is primarily associated with cell-mediated immune responses; (5) strong autoimmunity to myelin antigens is induced following the initial demyelination by virus-specific T cells $[14,30]$. Susceptible SJL mice preimmunized with viral peptides or UV-inactivated TMEV prior to viral infection preferentially mount protective $\mathrm{CD} 4^{+} \mathrm{T}$ cell (Th1) type responses, which in turn subsequently prevent the development of pathogenic Th17 cell responses [65,127]. The development of early protective $\mathrm{T}$ cell and/or antibody responses reduces the viral load and the consequent pathogenesis. The ratio between the protective antiviral immune responses and the level of viral load has an inverse relationship for the development of TMEV-induced demyelinating disease [136]. Therefore, excessive production of initial inflammatory cytokines due to the high viral load, reflecting high permissiveness and viral replication in susceptible mice, appears to play a pivotal role in the pathogenesis of TMEV-induced demyelinating disease [38]. The increased cytokine production and viral load are facilitated by TLR-mediated signals, including NF- $\mathrm{kB}$ activation, because the reduction of these signals by blocking TLR activation or NF- $\kappa B$ activation during viral infections hinders the pathogenesis of demyelinating disease $[61,66,73,219]$. Therefore, inhibition of either TLR signals or inhibitors of NF- $\mathrm{kB}$ may be helpful in controlling the development of TMEV-induced demyelinating disease. It is also interesting to note that the presence of antiviral cytokines such as type I IFNs by exposing TLR ligands prior to viral infection could inhibit the development of TMEV-induced demyelinating disease [63]. In addition, the reduction of IL-6 or IL-17A in 
genetically modified mice or by treating mice with anticytokine antibodies prevents the development of TMEV-induced demyelination $[63,65,75,83]$. Therefore, functional inhibition of key inflammatory cytokines, such as IL-6, IL-1 $\beta$, and/or IL-17, which are critical for the development of pathogenic $T$ cell responses and viral persistence, may prevent the pathogenesis of TMEV-induced demyelinating disease.

The pathogenic mechanisms of TMEV-IDD discussed above may be applicable to many other chronic inflammatory diseases associated with viral infections. For example, infections with closely related viruses, such as Coxsackie viruses are known to induce various chronic organ-specific immune-mediated inflammatory diseases in animals and humans [220]. It may also be applicable to the pathogenesis of other RNA viruses, such as Corona viruses, which also induce various neurological symptoms and autoimmunelike diseases, including cytokine storms linked to excessive production of innate immune responses $[221,222]$. Such excessive innate immune responses by chronic viral infections may also be associated with the pathogenesis of systematic lupus erythematosus [30]. Therefore, the TMEV-IDD system with well-defined pathogenic mechanisms may provide valuable information in understanding other virus-induced inflammatory diseases.

Funding: This work was supported by the United States Public Health Service Grants (RO1 NS28752 and RO1 NS33008) and a grant from the National Multiple Sclerosis Society (RG 4001-A6).

Institutional Review Board Statement: The study was conducted according to the guidelines of the Declaration of Helsinki, and approved by the Institutional Animal Care and Use Committee of Northwestern University (\#2011-1316, 1 April 2011 and \#2013-2133, 12 June 2013).

Informed Consent Statement: Not applicable.

Acknowledgments: I acknowledge all the colleagues who participated in the original contributions in the past years.

Conflicts of Interest: The author declares no conflict of interest. The funders had no role in the design of the study; in the collection, analyses, or interpretation of data; in the writing of the manuscript; or in the decision to publish the results.

$\begin{array}{ll}\text { Abbreviations } \\ \text { MS } & \text { multiple sclerosis } \\ \text { CNS } & \text { central nervous system } \\ \text { TMEV } & \text { Theiler's murine encephalomyelitis virus } \\ \text { TMEV-IDD } & \text { TMEV-induced demyelinating disease } \\ \text { PCR } & \text { polymerase chain reaction } \\ \text { PFU } & \text { plaque-forming unit } \\ \text { PI } & \text { post-infection } \\ \text { S mix } & \text { peptide mix derived from structural proteins } \\ \text { NS mix } & \text { peptide mix derived from nonstructural proteins } \\ \text { Tg } & \text { transgenic mice } \\ \text { TCR } & \text { T cell receptor } \\ \text { MHC } & \text { major histocompatibility complex }\end{array}$

\section{References}

1. Adams, R.M. Principles of Neurology; McGraw Hill: New York, NY, USA, 1977; p. 1041.

2. Johnson, R.T. The possible viral etiology of multiple sclerosis. Adv. Neurol. 1975, 13, 1-46. [PubMed]

3. McFarlin, D.E.; McFarland, H.F. Multiple sclerosis (first of two parts). N. Engl. J. Med. 1982, 307, 1183-1188. [CrossRef]

4. Soldan, S.S.; Berti, R.; Salem, N.; Secchiero, P.; Flamand, L.; Calabresi, P.A.; Brennan, M.B.; Maloni, H.W.; McFarland, H.F.; Lin, H.C.; et al. Association of human herpes virus 6 (HHV-6) with multiple sclerosis: Increased IgM response to HHV-6 early antigen and detection of serum HHV-6 DNA [see comments]. Nat. Med. 1997, 3, 1394-1397. [CrossRef] [PubMed]

5. Akhyani, N.; Berti, R.; Brennan, M.B.; Soldan, S.S.; Eaton, J.M.; McFarland, H.F.; Jacobson, S. Tissue distribution and variant characterization of human herpesvirus (HHV)-6: Increased prevalence of HHV-6A in patients with multiple sclerosis. J. Infect. Dis. 2000, 182, 1321-1325. [CrossRef] [PubMed] 
6. Alvarez-Lafuente, R.; Martin-Estefania, C.; de las Heras, V.; Castrillo, C.; Cour, I.; Picazo, J.J.; Varela De Seijas, E.; Arroyo, R. Prevalence of herpesvirus DNA in MS patients and healthy blood donors. Acta Neurol. Scand. 2002, 105, 95-99. [CrossRef] [PubMed]

7. Martinez, A.; Alvarez-Lafuente, R.; Mas, A.; Bartolome, M.; Garcia-Montojo, M.; de Las Heras, V.; de la Concha, E.G.; Arroyo, R.; Urcelay, E. Environment-gene interaction in multiple sclerosis: Human herpesvirus 6 and MHC2TA. Hum. Immunol. 2007, 68, 685-689. [CrossRef]

8. Buchmeier, M.J.; Lane, T.E. Viral-induced neurodegenerative disease. Curr. Opin. Microbiol. 1999, 2, 398-402. [CrossRef]

9. Daniels, J.B.; Pappenheimer, A.M.; Richardson, S. Observations on encephalomyelitis of mice (DA strain). J. Exp. Med. $1952,96,517$. [CrossRef]

10. Lipton, H.L. Theiler's virus infection in mice: An unusual biphasic disease process leading to demyelination. Infect. Immun. 1975, 11, 1147-1155. [CrossRef]

11. Wege, H.; Siddell, S.; ter Meulen, V. The biology and pathogenesis of coronaviruses. Curr. Top. Microbiol. Immunol. 1982, 99, 165-200.

12. Alford, E.C. Experimental Allergic Encephalomyelitis: A Useful Model for Multiple Sclerosis; A.R. Liss: New York, NY, USA, $1984 ;$ p. 554.

13. Dal Canto, M.C.; Kim, B.S.; Miller, S.D.; Melvold, R.W. Theiler's murine encephalomyelitis virus (TMEV)-induced demyelination: A model for human multiple clerosis. Methods 1996, 10, 453-461. [CrossRef] [PubMed]

14. Miller, S.D.; Vanderlugt, C.L.; Begolka, W.S.; Pao, W.; Yauch, R.L.; Neville, K.L.; Katz-Levy, Y.; Carrizosa, A.; Kim, B.S. Persistent infection with Theiler's virus leads to CNS autoimmunity via epitope spreading. Nat. Med. 1997, 3, 1133-1136. [CrossRef]

15. Liang, Z.; Kumar, A.S.; Jones, M.S.; Knowles, N.J.; Lipton, H.L. Phylogenetic Analysis of the Species Theilovirus: Emerging Murine and Human Pathogens. J. Virol. 2008, 82, 11545-11554. [CrossRef]

16. Chiu, C.Y.; Greninger, A.L.; Kanada, K.; Kwok, T.; Fischer, K.F.; Runckel, C.; Louie, J.K.; Glaser, C.A.; Yagi, S.; Schnurr, D.P.; et al. Identification of cardioviruses related to Theiler's murine encephalomyelitis virus in human infections. Proc. Natl. Acad. Sci. USA 2008, 105, 14124-14129. [CrossRef] [PubMed]

17. Zoll, J.; Erkens Hulshof, S.; Lanke, K.; Verduyn Lunel, F.; Melchers, W.J.; Schoondermark-van de Ven, E.; Roivainen, M.; Galama, J.M.; van Kuppeveld, F.J. Saffold virus, a human Theiler's-like cardiovirus, is ubiquitous and causes infection early in life. PLoS Pathog 2009, 5, e1000416. [CrossRef]

18. Theiler, M.; Gard, S. Encephalomyelitis of mice. J. Exp. Med. 1940, 72, 49-67. [CrossRef] [PubMed]

19. Lipton, H.L.; Friedmann, A. Purification of Theiler's murine encephalomyelitis virus and analysis of the structural virion polypeptides: Correlation of the polypeptide profile with virulence. J.Virol. 1980, 33, 1165-1172. [CrossRef] [PubMed]

20. Dal Canto, M.C.; Lipton, H.L. Primary demyelination in Theiler's virus infection. An ultrastructural study. Lab. Investig. 1975, 33, 626-637.

21. Lehrich, J.R.; Arnason, B.G.; Hochberg, F.H. Demyelinative myelopathy in mice induced by the DA virus. J. Neurol. Sci. 1976, 29, 149-160. [CrossRef]

22. Kang, B.S.; Yahikozawa, H.; Koh, C.S.; Kim, B.S. Oral administration of live virus protects susceptible mice from developing Theiler's virus-induced demyelinating disease. Virology 2007, 366, 185-196. [CrossRef]

23. Lipton, H.L.; Kim, B.S.; Yahikozawa, H.; Nadler, C.F. Serological evidence that Mus musculus is the natural host of Theiler's murine encephalomyelitis virus. Virus Res. 2001, 76, 79-86. [CrossRef]

24. DePaula-Silva, A.B.; Hanak, T.J.; Libbey, J.E.; Fujinami, R.S. Theiler's murine encephalomyelitis virus infection of SJL/J and C57BL/6J mice: Models for multiple sclerosis and epilepsy. J. Neuroimmunol. 2017, 308, 30-42. [CrossRef]

25. Gerhauser, I.; Alldinger, S.; Baumgartner, W. Ets-1 represents a pivotal transcription factor for viral clearance, inflammation, and demyelination in a mouse model of multiple sclerosis. J. Neuroimmunol. 2007, 188, 86-94. [CrossRef]

26. Wisniewski, H.M.; Bloom, B.R. Primary demyelination as a nonspecific consequence of a cell-mediated immune reaction. J. Exp. Med. 1975, 141, 346-359. [CrossRef] [PubMed]

27. Clatch, R.J.; Lipton, H.L.; Miller, S.D. Characterization of Theiler's murine encephalomyelitis virus (TMEV)-specific delayed-type hypersensitivity responses in TMEV-induced demyelinating disease: Correlation with clinical signs. J. Immunol. 1986, 136, 920-927.

28. Rauch, H.C.; Montgomery, I.N.; Hinman, C.L.; Harb, W.; Benjamins, J.A. Chronic Theiler's virus infection in mice: Appearance of myelin basic protein in the cerebrospinal fluid and serum antibody directed against MBP. J. Neuroimmunol. 1987, 14, 35-48. [CrossRef]

29. Yamada, M.; Zurbriggen, A.; Fujinami, R.S. Monoclonal antibody to Theiler's murine encephalomyelitis virus defines a determinant on myelin and oligodendrocytes, and augments demyelination in experimental allergic encephalomyelitis. J. Exp. Med. 1990, 171, 1893-1907. [CrossRef]

30. Jin, Y.H.; Kim, C.X.; Huang, J.; Kim, B.S. Infection and Activation of B Cells by Theiler's Murine Encephalomyelitis Virus (TMEV) Leads to Autoantibody Production in an Infectious Model of Multiple Sclerosis. Cells 2020, 9, 1787. [CrossRef] [PubMed]

31. Lipton, H.L.; Dal Canto, M.C. Susceptibility of inbred mice to chronic central nervous system infection by Theiler's murine encephalomyelitis virus. Infect. Immun. 1979, 26, 369-374. [CrossRef]

32. Rodriguez, M.; David, C.S. Demyelination induced by Theiler's virus: Influence of the H-2 haplotype. J. Immunol. 1985, 135, $2145-2148$.

33. Clatch, R.J.; Melvold, R.W.; Miller, S.D.; Lipton, H.L. Theiler's murine encephalomyelitis virus (TMEV)-induced demyelinating disease in mice is influenced by the H-2D region: Correlation with TEMV-specific delayed-type hypersensitivity. J. Immunol. 1985, 135, 1408-1414. [PubMed]

34. Rodriguez, M.; Leibowitz, J.; David, C.S. Susceptibility to Theiler's virus-induced demyelination. Mapping of the gene within the H-2D region. J. Exp. Med. 1986, 163, 620-631. [CrossRef] [PubMed] 
35. Kang, B.S.; Lyman, M.A.; Kim, B.S. The majority of infiltrating CD8+ T cells in the central nervous system of susceptible SJL/J mice infected with Theiler's virus are virus specific and fully functional. J. Virol. 2002, 76, 6577-6585. [CrossRef] [PubMed]

36. Lipton, H.L.; Melvold, R. Genetic analysis of susceptibility to Theiler's virus-induced demyelinating disease in mice. J. Immunol. 1984, 132, 1821-1825. [PubMed]

37. Jin, Y.H.; Kang, H.S.; Mohindru, M.; Kim, B.S. Preferential induction of protective T cell responses to Theiler's virus in resistant (C57BL/6 x SJL)F1 mice. J. Virol. 2011, 85, 3033-3040. [CrossRef] [PubMed]

38. Jin, Y.H.; Kang, H.S.; Hou, W.; Meng, L.; Kim, B.S. The level of viral infection of antigen-presenting cells correlates with the level of development of Theiler's murine encephalomyelitis virus-induced demyelinating disease. J. Virol. 2015, 89, 1867-1878. [CrossRef]

39. Bureau, J.F.; Montagutelli, X.; Lefebvre, S.; Guenet, J.L.; Pla, M.; Brahic, M. The interaction of two groups of murine genes determines the persistence of Theiler's virus in the central nervous system. J. Virol. 1992, 66, 4698-4704. [CrossRef]

40. Bureau, J.F.; Montagutelli, X.; Bihl, F.; Lefebvre, S.; Guenet, J.L.; Brahic, M. Mapping loci influencing the persistence of Theiler's virus in the murine central nervous system. Nat. Genet. 1993, 5, 87-91. [CrossRef]

41. Bureau, J.F.; Drescher, K.M.; Pease, L.R.; Vikoren, T.; Delcroix, M.; Zoecklein, L.; Brahic, M.; Rodriguez, M. Chromosome 14 contains determinants that regulate susceptibility to Theiler's virus-induced demyelination in the mouse. Genetics 1998, 148, 1941-1949. [CrossRef]

42. Rodriguez, M.; Leibowitz, J.L.; Lampert, P.W. Persistent infection of oligodendrocytes in Theiler's virus-induced encephalomyelitis. Ann. Neurol. 1983, 13, 426-433. [CrossRef]

43. Lipton, H.L.; Kratochvil, J.; Sethi, P.; Dal Canto, M.C. Theiler's virus antigen detected in mouse spinal cord $21 / 2$ years after infection. Neurology 1984, 34, 1117-1119. [CrossRef] [PubMed]

44. Yamada, M.; Zurbriggen, A.; Fujinami, R.S. The relationship between viral RNA, myelin-specific mRNAs, and demyelination in central nervous system disease during Theiler's virus infection. Am. J. Pathol. 1990, 137, 1467-1479. [PubMed]

45. McAllister, A.; Tangy, F.; Aubert, C.; Brahic, M. Genetic mapping of the ability of Theiler's virus to persist and demyelinate. J. Virol. 1990, 64, 4252-4257. [CrossRef] [PubMed]

46. Tangy, F.; McAllister, A.; Aubert, C.; Brahic, M. Determinants of persistence and demyelination of the DA strain of Theiler's virus are found only in the VP1 gene. J. Virol. 1991, 65, 1616-1618. [CrossRef]

47. Lipton, H.L.; Calenoff, M.; Bandyopadhyay, P.; Miller, S.D.; Dal Canto, M.C.; Gerety, S.; Jensen, K. The $5^{\prime}$ noncoding sequences from a less virulent Theiler's virus dramatically attenuate GDVII neurovirulence. J. Virol. 1991, 65, 4370-4377. [CrossRef]

48. Pullen, L.C.; Park, S.H.; Miller, S.D.; Dal Canto, M.C.; Kim, B.S. Treatment with bacterial LPS renders genetically resistant C57BL/ 6 mice susceptible to Theiler's virus-induced demyelinating disease. J. Immunol. 1995, 155, 4497-4503.

49. Myoung, J.; Il Bahk, Y.; Kang, H.S.; Dal Canto, M.C.; Kim, B.S. Anti-capsid immunity level, not viral persistence level, correlates with the progression of Theiler's virus-induced demyelinating disease in viral P1-transgenic mice. J. Virol. 2008, 82, 5606-5617. [CrossRef] [PubMed]

50. Anderson, R.; Harting, E.; Frey, M.S.; Leibowitz, J.L.; Miranda, R.C. Theiler's murine encephalomyelitis virus induces rapid necrosis and delayed apoptosis in myelinated mouse cerebellar explant cultures. Brain Res. 2000, 868, 259-267. [CrossRef]

51. Palma, J.P.; Kim, B.S. Induction of selected chemokines in glial cells infected with Theiler's virus. J. Neuroimmunol. 2001, 117, 166-170. [CrossRef]

52. Zheng, L.; Calenoff, M.A.; Dal Canto, M.C. Astrocytes, not microglia, are the main cells responsible for viral persistence in Theiler's murine encephalomyelitis virus infection leading to demyelination. J. Neuroimmunol. 2001, 118, 256-267. [CrossRef]

53. Lipton, H.L.; Kumar, A.S.; Trottier, M. Theiler's virus persistence in the central nervous system of mice is associated with continuous viral replication and a difference in outcome of infection of infiltrating macrophages versus oligodendrocytes. Virus Res. 2005, 111, 214-223. [CrossRef] [PubMed]

54. Katz-Levy, Y.; Neville, K.L.; Girvin, A.M.; Vanderlugt, C.L.; Pope, J.G.; Tan, L.J.; Miller, S.D. Endogenous presentation of self myelin epitopes by CNS-resident APCs in Theiler's virus-infected mice. J. Clin. Investig. 1999, 104, 599-610. [CrossRef] [PubMed]

55. Palma, J.P.; Yauch, R.L.; Lang, S.; Kim, B.S. Potential role of CD4+ T cell-mediated apoptosis of activated astrocytes in Theiler's virus-induced demyelination. J. Immunol. 1999, 162, 6543-6551.

56. Olson, J.K.; Girvin, A.M.; Miller, S.D. Direct activation of innate and antigen-presenting functions of microglia following infection with Theiler's virus. J. Virol. 2001, 75, 9780-9789. [CrossRef]

57. Clatch, R.J.; Miller, S.D.; Metzner, R.; Dal Canto, M.C.; Lipton, H.L. Monocytes/macrophages isolated from the mouse central nervous system contain infectious Theiler's murine encephalomyelitis virus (TMEV). Virology 1990, 176, 244-254. [CrossRef]

58. Olson, J.K.; Miller, S.D. Microglia initiate central nervous system innate and adaptive immune responses through multiple TLRs. J. Immunol. 2004, 173, 3916-3924. [CrossRef]

59. Jin, Y.H.; Mohindru, M.; Kang, M.H.; Fuller, A.C.; Kang, B.; Gallo, D.; Kim, B.S. Differential virus replication, cytokine production, and antigen-presenting function by microglia from susceptible and resistant mice infected with Theiler's virus. J. Virol. 2007, 81, 11690-11702. [CrossRef] [PubMed]

60. Son, K.N.; Becker, R.P.; Kallio, P.; Lipton, H.L. Theiler's virus-induced intrinsic apoptosis in M1-D macrophages is Bax mediated and restricts virus infectivity: A mechanism for persistence of a cytolytic virus. J. Virol. 2008, 82, 4502-4510. [CrossRef]

61. Kang, M.H.; So, E.Y.; Park, H.; Kim, B.S. Replication of Theiler's virus requires NF-kappaB-activation: Higher viral replication and spreading in astrocytes from susceptible mice. Glia 2008, 56, 942-953. [CrossRef] 
62. Schneider, K.M.; Watson, N.B.; Minchenberg, S.B.; Massa, P.T. The influence of macrophage growth factors on Theiler's Murine Encephalomyelitis Virus (TMEV) infection and activation of macrophages. Cytokine 2018, 102, 83-93. [CrossRef] [PubMed]

63. Hou, W.; So, E.Y.; Kim, B.S. Role of dendritic cells in differential susceptibility to viral demyelinating disease. PLoS Pathog 2007, 3, e124. [CrossRef] [PubMed]

64. McMahon, E.J.; Bailey, S.L.; Castenada, C.V.; Waldner, H.; Miller, S.D. Epitope spreading initiates in the CNS in two mouse models of multiple sclerosis. Nat. Med. 2005, 11, 335-339. [CrossRef]

65. Hou, W.; Kang, H.S.; Kim, B.S. Th17 cells enhance viral persistence and inhibit T cell cytotoxicity in a model of chronic virus infection. J. Exp. Med. 2009, 206, 313-328. [CrossRef] [PubMed]

66. Jin, Y.H.; Kaneyama, T.; Kang, M.H.; Kang, H.S.; Koh, C.S.; Kim, B.S. TLR3 signaling is either protective or pathogenic for the development of Theiler's virus-induced demyelinating disease depending on the time of viral infection. J. Neuroinflamm. 2011, 8, 178. [CrossRef] [PubMed]

67. Chang, J.R.; Zaczynska, E.; Katsetos, C.D.; Platsoucas, C.D.; Oleszak, E.L. Differential expression of TGF-beta, IL-2, and other cytokines in the CNS of Theiler's murine encephalomyelitis virus-infected susceptible and resistant strains of mice. Virology 2000, 278, 346-360. [CrossRef]

68. Petro, T.M. Disparate expression of IL-12 by SJL/J and B10.S macrophages during Theiler's virus infection is associated with activity of TLR7 and mitogen-activated protein kinases. Microbes Infect. 2005, 7, 224-232. [CrossRef]

69. Moore, T.C.; Bush, K.L.; Cody, L.; Brown, D.M.; Petro, T.M. Control of early Theiler's murine encephalomyelitis virus replication in macrophages by interleukin-6 occurs in conjunction with STAT1 activation and nitric oxide production. J. Virol. 2012, 86, 10841-10851. [CrossRef]

70. So, E.Y.; Kang, M.H.; Kim, B.S. Induction of chemokine and cytokine genes in astrocytes following infection with Theiler's murine encephalomyelitis virus is mediated by the Toll-like receptor 3. Glia 2006, 53, 858-867. [CrossRef]

71. Turrin, N.P. Central nervous system Toll-like receptor expression in response to Theiler's murine encephalomyelitis virus-induced demyelination disease in resistant and susceptible mouse strains. Virol. J. 2008, 5, 154. [CrossRef]

72. So, E.Y.; Kim, B.S. Theiler's virus infection induces TLR3-dependent upregulation of TLR2 critical for proinflammatory cytokine production. Glia 2009, 57, 1216-1226. [CrossRef]

73. Palma, J.P.; Kwon, D.; Clipstone, N.A.; Kim, B.S. Infection with Theiler's murine encephalomyelitis virus directly induces proinflammatory cytokines in primary astrocytes via NF-kappaB activation: Potential role for the initiation of demyelinating disease. J. Virol. 2003, 77, 6322-6331. [CrossRef] [PubMed]

74. Jin, Y.H.; Kim, S.J.; So, E.Y.; Meng, L.; Colonna, M.; Kim, B.S. Melanoma differentiation-associated gene 5 is critical for protection against Theiler's virus-induced demyelinating disease. J. Virol. 2012, 86, 1531-1543. [CrossRef]

75. Hou, W.; Jin, Y.H.; Kang, H.S.; Kim, B.S. Interleukin-6 (IL-6) and IL-17 Synergistically Promote Viral Persistence by Inhibiting Cellular Apoptosis and Cytotoxic T Cell Function. J. Virol. 2014, 88, 8479-8489. [CrossRef] [PubMed]

76. Carpentier, P.A.; Williams, B.R.; Miller, S.D. Distinct roles of protein kinase R and toll-like receptor 3 in the activation of astrocytes by viral stimuli. Glia 2007, 55, 239-252. [CrossRef]

77. Kanneganti, T.D.; Body-Malapel, M.; Amer, A.; Park, J.H.; Whitfield, J.; Franchi, L.; Taraporewala, Z.F.; Miller, D.; Patton, J.T.; Inohara, N.; et al. Critical role for Cryopyrin/Nalp3 in activation of caspase-1 in response to viral infection and double-stranded RNA. J. Biol. Chem. 2006, 281, 36560-36568. [CrossRef]

78. Ichinohe, T.; Lee, H.K.; Ogura, Y.; Flavell, R.; Iwasaki, A. Inflammasome recognition of influenza virus is essential for adaptive immune responses. J. Exp. Med. 2009, 206, 79-87. [CrossRef]

79. Allen, I.C.; Scull, M.A.; Moore, C.B.; Holl, E.K.; McElvania-TeKippe, E.; Taxman, D.J.; Guthrie, E.H.; Pickles, R.J.; Ting, J.P. The NLRP3 inflammasome mediates in vivo innate immunity to influenza A virus through recognition of viral RNA. Immunity 2009, 30, 556-565. [CrossRef] [PubMed]

80. Delaloye, J.; Roger, T.; Steiner-Tardivel, Q.G.; Le Roy, D.; Knaup Reymond, M.; Akira, S.; Petrilli, V.; Gomez, C.E.; Perdiguero, B.; Tschopp, J.; et al. Innate immune sensing of modified vaccinia virus Ankara (MVA) is mediated by TLR2-TLR6, MDA-5 and the NALP3 inflammasome. PLoS Pathog 2009, 5, e1000480. [CrossRef] [PubMed]

81. Subramanian, N.; Natarajan, K.; Clatworthy, M.R.; Wang, Z.; Germain, R.N. The adaptor MAVS promotes NLRP3 mitochondrial localization and inflammasome activation. Cell 2013, 153, 348-361. [CrossRef]

82. Kim, S.J.; Jin, Y.H.; Kim, B.S. Prostaglandin E2 produced following infection with Theiler's virus promotes the pathogenesis of demyelinating disease. PLoS ONE 2017, 12, e0176406. [CrossRef]

83. Kim, B.S.; Jin, Y.H.; Meng, L.; Hou, W.; Kang, H.S.; Park, H.S.; Koh, C.S. IL-1 signal affects both protection and pathogenesis of virus-induced chronic CNS demyelinating disease. J. Neuroinflamm. 2012, 9, 217. [CrossRef] [PubMed]

84. Guidotti, L.G.; Chisari, F.V. Noncytolytic control of viral infections by the innate and adaptive immune response. Annu. Rev. Immunol. 2001, 19, 65-91. [CrossRef] [PubMed]

85. Fontana, A.; Constam, D.; Frei, K.; Koedel, U.; Pfister, W.; Weller, M. Cytokines and defense against CNS infection. In Cytokines and the CNS; Ransohoff, R.M., Benveniste, E.N., Eds.; CRC Press: Boca Raton, FL, USA, 1996; pp. 188-219.

86. Ludewig, B.; Junt, T.; Hengartner, H.; Zinkernagel, R.M. Dendritic cells in autoimmune diseases. Curr. Opin. Immunol. 2001, 13, 657-662. [CrossRef]

87. Asensio, V.C.; Campbell, I.L. Chemokine gene expression in the brains of mice with lymphocytic choriomeningitis. J. Virol. 1997, 71, 7832-7840. [CrossRef] 
88. Lane, T.E.; Asensio, V.C.; Yu, N.; Paoletti, A.D.; Campbell, I.L.; Buchmeier, M.J. Dynamic regulation of alpha- and beta-chemokine expression in the central nervous system during mouse hepatitis virus-induced demyelinating disease. J. Immunol. 1998, 160, 970-978.

89. Hoffman, L.M.; Fife, B.T.; Begolka, W.S.; Miller, S.D.; Karpus, W.J. Central nervous system chemokine expression during Theiler's virus-induced demyelinating disease. J. Neurovirol. 1999, 5, 635-642. [CrossRef]

90. Noe, K.H.; Cenciarelli, C.; Moyer, S.A.; Rota, P.A.; Shin, M.L. Requirements for measles virus induction of RANTES chemokine in human astrocytoma-derived U373 cells. J. Virol. 1999, 73, 3117-3124. [CrossRef] [PubMed]

91. Lane, T.E.; Liu, M.T.; Chen, B.P.; Asensio, V.C.; Samawi, R.M.; Paoletti, A.D.; Campbell, I.L.; Kunkel, S.L.; Fox, H.S.; Buchmeier, M.J. A central role for CD4(+) T cells and RANTES in virus-induced central nervous system inflammation and demyelination. J. Virol. 2000, 74, 1415-1424. [CrossRef]

92. Theil, D.J.; Tsunoda, I.; Libbey, J.E.; Derfuss, T.J.; Fujinami, R.S. Alterations in cytokine but not chemokine mRNA expression during three distinct Theiler's virus infections. J. Neuroimmunol. 2000, 104, 22-30. [CrossRef]

93. Palma, J.P.; Kim, B.S. The scope and activation mechanisms of chemokine gene expression in primary astrocytes following infection with Theiler's virus. J. Neuroimmunol. 2004, 149, 121-129. [CrossRef]

94. Rubio, N.; Sanz-Rodriguez, F.; Lipton, H.L. Theiler's virus induces the MIP-2 chemokine (CXCL2) in astrocytes from genetically susceptible but not from resistant mouse strains. Cell. Immunol. 2006, 239, 31-40. [CrossRef] [PubMed]

95. Rubio, N.; Sanz-Rodriguez, F. Induction of the CXCL1 (KC) chemokine in mouse astrocytes by infection with the murine encephalomyelitis virus of Theiler. Virology 2007, 358, 98-108. [CrossRef] [PubMed]

96. Karpus, W.J.; Kennedy, K.J.; Fife, B.T.; Bennett, J.L.; Dal Canto, M.C.; Kunkel, S.L.; Lukacs, N.W. Anti-CCL2 treatment inhibits Theiler's murine encephalomyelitis virus-induced demyelinating disease. J. Neurovirol. 2006, 12, 251-261. [CrossRef] [PubMed]

97. Kang, M.H.; Jin, Y.H.; Kim, B.S. Effects of Keratinocyte-Derived Cytokine (CXCL-1) on the Development of Theiler's Virus-Induced Demyelinating Disease. Front. Cell. Infect. Microbiol. 2018, 8, 9. [CrossRef]

98. Olson, J.K. Effect of the innate immune response on development of Theiler's murine encephalomyelitis virus-induced demyelinating disease. J. Neurovirol. 2014, 20, 427-436. [CrossRef] [PubMed]

99. Inoue, A.; Koh, C.S.; Yamazaki, M.; Ichikawa, M.; Isobe, M.; Ishihara, Y.; Yagita, H.; Kim, B.S. Anti-adhesion molecule therapy in Theiler's murine encephalomyelitis virus-induced demyelinating disease. Int. Immunol. 1997, 9, 1837-1847. [CrossRef] [PubMed]

100. Pozner, R.G.; Berria, M.I.; Negrotto, S.; Schattner, M.; Gomez, R.M. Differential astrocyte response to Theiler's murine encephalomyelitis virus infection. Intervirology 2005, 48, 279-284. [CrossRef]

101. Rubio, N.; Sanz-Rodriguez, F.; Arevalo, M.A. Up-regulation of the vascular cell adhesion molecule-1 (VCAM-1) induced by Theiler's murine encephalomyelitis virus infection of murine brain astrocytes. Cell Commun. Adhes. 2010, 17, 57-68. [CrossRef]

102. Jin, Y.H.; Kang, B.; Kang, H.S.; Koh, C.S.; Kim, B.S. Endothelin-1 contributes to the development of virus-induced demyelinating disease. J. Neuroinflamm. 2020, 17, 307. [CrossRef]

103. Inoue, A.; Koh, C.S.; Yahikozawa, H.; Yanagisawa, N.; Yagita, H.; Ishihara, Y.; Kim, B.S. The level of tumor necrosis factor-alpha producing cells in the spinal cord correlates with the degree of Theiler's murine encephalomyelitis virus-induced demyelinating disease. Int. Immunol. 1996, 8, 1001-1008. [CrossRef]

104. Rodriguez, M.; Zoecklein, L.; Papke, L.; Gamez, J.; Denic, A.; Macura, S.; Howe, C. Tumor necrosis factor alpha is reparative via TNFR2 [corrected] in the hippocampus and via TNFR1 [corrected] in the striatum after virus-induced encephalitis. Brain Pathol. 2009, 19, 12-26. [CrossRef]

105. Swanson, K.V.; Deng, M.; Ting, J.P. The NLRP3 inflammasome: Molecular activation and regulation to therapeutics. Nat. Rev. Immunol. 2019, 19, 477-489. [CrossRef]

106. Weinlich, R.; Bortoluci, K.R.; Chehab, C.F.; Serezani, C.H.; Ulbrich, A.G.; Peters-Golden, M.; Russo, M.; Amarante-Mendes, G.P. TLR4/MYD88-dependent, LPS-induced synthesis of PGE2 by macrophages or dendritic cells prevents anti-CD3-mediated CD95L upregulation in T cells. Cell Death Differ. 2008, 15, 1901-1909. [CrossRef] [PubMed]

107. Jin, Y.H.; Hou, W.; Kang, H.S.; Koh, C.S.; Kim, B.S. The role of interleukin-6 in the expression of PD-1 and PDL-1 on central nervous system cells following infection with Theiler's murine encephalomyelitis virus. J. Virol. 2013, 87, 11538-11551. [CrossRef] [PubMed]

108. Chan, L.C.; Li, C.W.; Xia, W.; Hsu, J.M.; Lee, H.H.; Cha, J.H.; Wang, H.L.; Yang, W.H.; Yen, E.Y.; Chang, W.C.; et al. IL-6/JAK1 pathway drives PD-L1 Y112 phosphorylation to promote cancer immune evasion. J. Clin. Investig. 2019, 129, 3324-3338. [CrossRef] [PubMed]

109. Delhaye, S.; Paul, S.; Blakqori, G.; Minet, M.; Weber, F.; Staeheli, P.; Michiels, T. Neurons produce type I interferon during viral encephalitis. Proc. Natl. Acad. Sci. USA 2006, 103, 7835-7840. [CrossRef]

110. Rubio, N.; Palomo, M.; Alcami, A. Interferon-alpha/beta genes are up-regulated in murine brain astrocytes after infection with Theiler's murine encephalomyelitis virus. J. Interferon Cytokine Res. 2010, 30, 253-262. [CrossRef]

111. Njenga, M.K.; Pease, L.R.; Wettstein, P.; Mak, T.; Rodriguez, M. Interferon alpha/beta mediates early virus-induced expression of H-2D and H-2K in the central nervous system. Lab. Investig. 1997, 77, 71-84. [PubMed]

112. Rodriguez, M.; Roos, R.P.; McGavern, D.; Zoecklein, L.; Pavelko, K.; Sang, H.; Lin, X. The CD4-mediated immune response is critical in determining the outcome of infection using Theiler's viruses with VP1 capsid protein point mutations. Virology 2000, 275, 9-19. [CrossRef]

113. Jin, Y.H.; Hou, W.; Kim, S.J.; Fuller, A.C.; Kang, B.; Goings, G.; Miller, S.D.; Kim, B.S. Type I interferon signals control Theiler's virus infection site, cellular infiltration and T cell stimulation in the CNS. J. Neuroimmunol. 2010, 226, 27-37. [CrossRef] 
114. Ben-Sasson, S.Z.; Hu-Li, J.; Quiel, J.; Cauchetaux, S.; Ratner, M.; Shapira, I.; Dinarello, C.A.; Paul, W.E. IL-1 acts directly on CD4 T cells to enhance their antigen-driven expansion and differentiation. Proc. Natl. Acad. Sci. USA 2009, 106, 7119-7124. [CrossRef]

115. Rodriguez, M.; Pavelko, K.D.; McKinney, C.W.; Leibowitz, J.L. Recombinant human IL-6 suppresses demyelination in a viral model of multiple sclerosis. J. Immunol. 1994, 153, 3811-3821. [PubMed]

116. Lauder, S.N.; Jones, E.; Smart, K.; Bloom, A.; Williams, A.S.; Hindley, J.P.; Ondondo, B.; Taylor, P.R.; Clement, M.; Fielding, C.; et al Interleukin-6 limits influenza-induced inflammation and protects against fatal lung pathology. Eur. J. Immunol. 2013, 43, $2613-2625$. [CrossRef]

117. Harker, J.A.; Lewis, G.M.; Mack, L.; Zuniga, E.I. Late interleukin-6 escalates T follicular helper cell responses and controls a chronic viral infection. Science 2011, 334, 825-829. [CrossRef] [PubMed]

118. Lipton, H.L.; Canto, C.D. Contrasting effects of immunosuppression on Theiler's virus infection in mice. Infect. Immun. 1977, 15, 903-909. [CrossRef] [PubMed]

119. Rodriguez, M.; Lafuse, W.P.; Leibowitz, J.; David, C.S. Partial suppression of Theiler's virus-induced demyelination in vivo by administration of monoclonal antibodies to immune-response gene products (Ia antigens). Neurology 1986, 36, 964-970. [CrossRef]

120. Welsh, C.J.; Tonks, P.; Nash, A.A.; Blakemore, W.F. The effect of L3T4 T cell depletion on the pathogenesis of Theiler's murine encephalomyelitis virus infection in CBA mice. J.Gen.Virol. 1987, 68, 1659-1667. [CrossRef]

121. Clatch, R.J.; Lipton, H.L.; Miller, S.D. Class II-restricted T cell responses in Theiler's murine encephalomyelitis virus (TMEV)induced demyelinating disease. II. Survey of host immune responses and central nervous system virus titers in inbred mouse strains. Microb. Pathog. 1987, 3, 327-337. [CrossRef]

122. Inoue, A.; Choe, Y.K.; Kim, B.S. Analysis of antibody responses to predominant linear epitopes of Theiler's murine encephalomyelitis virus. J. Virol. 1994, 68, 3324-3333. [CrossRef]

123. Melvold, R.W.; Jokinen, D.M.; Knobler, R.L.; Lipton, H.L. Variations in genetic control of susceptibility to Theiler's murine encephalomyelitis virus (TMEV)-induced demyelinating disease. I. Differences between susceptible SJL/J and resistant BALB/c strains map near the T cell beta-chain constant gene on chromosome 6. J. Immunol. 1987, 138, 1429-1433.

124. Bahk, Y.Y.; Kappel, C.A.; Rasmussen, G.; Kim, B.S. Association between susceptibility to Theiler's virus-induced demyelination and T-cell receptor J beta1-C beta1 polymorphism rather than V beta deletion. J. Virol. 1997, 71, 4181-4185. [CrossRef]

125. Gerety, S.J.; Rundell, M.K.; Dal Canto, M.C.; Miller, S.D. Class II-restricted T cell responses in Theiler's murine encephalomyelitis virus-induced demyelinating disease. VI. Potentiation of demyelination with and characterization of an immunopathologic CD4+ T cell line specific for an immunodominant VP2 epitope. J. Immunol. 1994, 152, 919-929. [PubMed]

126. Yauch, R.L.; Kim, B.S. A predominant viral epitope recognized by T cells from the periphery and demyelinating lesions of SJL/J mice infected with Theiler's virus is located within VP1(233-244). J. Immunol. 1994, 153, 4508-4519.

127. Yauch, R.L.; Palma, J.P.; Yahikozawa, H.; Koh, C.S.; Kim, B.S. Role of individual T-cell epitopes of Theiler's virus in the pathogenesis of demyelination correlates with the ability to induce a Th1 response. J. Virol. 1998, 72, 6169-6174. [CrossRef] [PubMed]

128. Crane, M.A.; Yauch, R.; Dal Canto, M.C.; Kim, B.S. Effect of immunization with Theiler's virus on the course of demyelinating disease. J. Neuroimmunol. 1993, 45, 67-73. [CrossRef]

129. Njenga, M.K.; Pavelko, K.D.; Baisch, J.; Lin, X.; David, C.; Leibowitz, J.; Rodriguez, M. Theiler's virus persistence and demyelination in major histocompatibility complex class II-deficient mice. J. Virol. 1996, 70, 1729-1737. [CrossRef] [PubMed]

130. Karls, K.A.; Denton, P.W.; Melvold, R.W. Susceptibility to Theiler's murine encephalomyelitis virus-induced demyelinating disease in BALB/cAnNCr mice is related to absence of a CD4+ T-cell subset. Mult. Scler. 2002, 8, 469-474. [CrossRef]

131. Gerety, S.J.; Karpus, W.J.; Cubbon, A.R.; Goswami, R.G.; Rundell, M.K.; Peterson, J.D.; Miller, S.D. Class II-restricted T cell responses in Theiler's murine encephalomyelitis virus-induced demyelinating disease. V. Mapping of a dominant immunopathologic VP2 T cell epitope in susceptible SJL/J mice. J. Immunol. 1994, 152, 908-918.

132. Yauch, R.L.; Kerekes, K.; Saujani, K.; Kim, B.S. Identification of a major T-cell epitope within VP3 amino acid residues 24 to 37 of Theiler's virus in demyelination-susceptible SJL/J mice. J. Virol. 1995, 69, 7315-7318. [CrossRef]

133. Jin, Y.H.; Kang, B.; Kim, B.S. Theiler's virus infection induces a predominant pathogenic CD4+ T cell response to RNA polymerase in susceptible SJL/J mice. J. Virol. 2009, 83, 10981-10992. [CrossRef]

134. Kang, B.; Kang, H.K.; Kim, B.S. Identification of capsid epitopes of Theiler's virus recognized by CNS-infiltrating CD4(+) T cells from virus-infected C57BL/6 mice. Virus Res. 2005, 108, 57-61. [CrossRef] [PubMed]

135. Johnson, A.J.; Mendez-Fernandez, Y.; Moyer, A.M.; Sloma, C.R.; Pirko, I.; Block, M.S.; Rodriguez, M.; Pease, L.R. Antigen-specific CD8+ T cells mediate a peptide-induced fatal syndrome. J. Immunol. 2005, 174, 6854-6862. [CrossRef] [PubMed]

136. Kang, H.S.; Hou, W.; Kim, B.S. Rapid expansion of virus-specific CD4+ T cell types in the CNS of susceptible mice infected with Theiler's virus. Int. J. Mol. Sci. 2020, 21, 7719. [CrossRef]

137. Palma, J.P.; Yauch, R.L.; Kang, H.K.; Lee, H.G.; Kim, B.S. Preferential induction of IL-10 in APC correlates with a switch from Th1 to Th2 response following infection with a low pathogenic variant of Theiler's virus. J. Immunol. 2002, 168, 4221-4230. [CrossRef] [PubMed]

138. Mohindru, M.; Kang, B.; Kim, B.S. Initial capsid-specific CD4(+) T cell responses protect against Theiler's murine encephalomyelitisvirus-induced demyelinating disease. Eur. J. Immunol. 2006, 36, 2106-2115. [CrossRef] [PubMed]

139. Fiette, L.; Aubert, C.; Muller, U.; Huang, S.; Aguet, M.; Brahic, M.; Bureau, J.F. Theiler's virus infection of 129 Sv mice that lack the interferon alpha/beta or interferon gamma receptors. J. Exp. Med. 1995, 181, 2069-2076. [CrossRef] 
140. Rodriguez, M.; Zoecklein, L.J.; Howe, C.L.; Pavelko, K.D.; Gamez, J.D.; Nakane, S.; Papke, L.M. Gamma interferon is critical for neuronal viral clearance and protection in a susceptible mouse strain following early intracranial Theiler's murine encephalomyelitis virus infection. J. Virol. 2003, 77, 12252-12265. [CrossRef]

141. Pullen, L.C.; Miller, S.D.; Dal Canto, M.C.; Van der Meide, P.H.; Kim, B.S. Alteration in the level of interferon-gamma results in acceleration of Theiler's virus-induced demyelinating disease. J. Neuroimmunol. 1994, 55, 143-152. [CrossRef]

142. Rodriguez, M.; Pavelko, K.; Coffman, R.L. Gamma interferon is critical for resistance to Theiler's virus-induced demyelination. J. Virol. 1995, 69, 7286-7290. [CrossRef]

143. Murray, P.D.; McGavern, D.B.; Pease, L.R.; Rodriguez, M. Cellular sources and targets of IFN-gamma-mediated protection against viral demyelination and neurological deficits. Eur. J. Immunol. 2002, 32, 606-615. [CrossRef]

144. Harrington, L.E.; Hatton, R.D.; Mangan, P.R.; Turner, H.; Murphy, T.L.; Murphy, K.M.; Weaver, C.T. Interleukin 17-producing CD4+ effector T cells develop via a lineage distinct from the T helper type 1 and 2 lineages. Nat. Immunol. 2005, 6, 1123-1132. [CrossRef] [PubMed]

145. Park, H.; Li, Z.; Yang, X.O.; Chang, S.H.; Nurieva, R.; Wang, Y.H.; Wang, Y.; Hood, L.; Zhu, Z.; Tian, Q.; et al. A distinct lineage of CD4 T cells regulates tissue inflammation by producing interleukin 17. Nat. Immunol. 2005, 6, 1133-1141. [CrossRef] [PubMed]

146. Steinman, L. A brief history of $\mathrm{T}(\mathrm{H}) 17$, the first major revision in the $\mathrm{T}(\mathrm{H}) 1 / \mathrm{T}(\mathrm{H}) 2$ hypothesis of $\mathrm{T}$ cell-mediated tissue damage. Nat. Med. 2007, 13, 139-145. [CrossRef] [PubMed]

147. Veldhoen, M.; Hocking, R.J.; Atkins, C.J.; Locksley, R.M.; Stockinger, B. TGFbeta in the context of an inflammatory cytokine milieu supports de novo differentiation of IL-17-producing T cells. Immunity 2006, 24, 179-189. [CrossRef] [PubMed]

148. Onishi, R.M.; Gaffen, S.L. Interleukin-17 and its target genes: Mechanisms of interleukin-17 function in disease. Immunology 2010, 129, 311-321. [CrossRef] [PubMed]

149. Martinez, N.E.; Sato, F.; Kawai, E.; Omura, S.; Takahashi, S.; Yoh, K.; Tsunoda, I. Th17-biased RORgammat transgenic mice become susceptible to a viral model for multiple sclerosis. Brain Behav. Immun. 2015, 43, 86-97. [CrossRef]

150. Richards, M.H.; Getts, M.T.; Podojil, J.R.; Jin, Y.H.; Kim, B.S.; Miller, S.D. Virus expanded regulatory T cells control disease severity in the Theiler's virus mouse model of MS. J. Autoimmun. 2011, 36, 142-154. [CrossRef]

151. Zhao, J.; Zhao, J.; Perlman, S. Virus-specific regulatory T cells ameliorate encephalitis by repressing effector T cell functions from priming to effector stages. PLoS Pathog 2014, 10, e1004279. [CrossRef] [PubMed]

152. Nawijn, M.C.; Motta, A.C.; Gras, R.; Shirinbak, S.; Maazi, H.; van Oosterhout, A.J. TLR-2 activation induces regulatory T cells and long-term suppression of asthma manifestations in mice. PLoS ONE 2013, 8, e55307. [CrossRef]

153. Yamazaki, S.; Okada, K.; Maruyama, A.; Matsumoto, M.; Yagita, H.; Seya, T. TLR2-dependent induction of IL-10 and Foxp3+ CD25+ CD4+ regulatory T cells prevents effective anti-tumor immunity induced by Pam2 lipopeptides in vivo. PLoS ONE 2011, 6, e18833. [CrossRef] [PubMed]

154. Prajeeth, C.K.; Beineke, A.; Iskandar, C.D.; Gudi, V.; Herder, V.; Gerhauser, I.; Haist, V.; Teich, R.; Huehn, J.; Baumgartner, W.; et al. Limited role of regulatory $\mathrm{T}$ cells during acute Theiler virus-induced encephalitis in resistant C57BL/6 mice. J. Neuroinflamm. 2014, 11, 180. [CrossRef]

155. Chen, W.; Jin, W.; Hardegen, N.; Lei, K.J.; Li, L.; Marinos, N.; McGrady, G.; Wahl, S.M. Conversion of peripheral CD4+CD25- naive T cells to CD4+CD25+ regulatory T cells by TGF-beta induction of transcription factor Foxp3. J. Exp. Med. 2003, 198, 1875-1886. [CrossRef] [PubMed]

156. Walker, M.R.; Kasprowicz, D.J.; Gersuk, V.H.; Benard, A.; Van Landeghen, M.; Buckner, J.H.; Ziegler, S.F. Induction of FoxP3 and acquisition of T regulatory activity by stimulated human CD4+CD25- T cells. J. Clin. Investig. 2003, 112, 1437-1443. [CrossRef]

157. Zelenay, S.; Lopes-Carvalho, T.; Caramalho, I.; Moraes-Fontes, M.F.; Rebelo, M.; Demengeot, J. Foxp3+ CD25- CD4 T cells constitute a reservoir of committed regulatory cells that regain CD25 expression upon homeostatic expansion. Proc. Natl. Acad. Sci. USA 2005, 102, 4091-4096. [CrossRef] [PubMed]

158. Stoop, J.N.; Claassen, M.A.; Woltman, A.M.; Binda, R.S.; Kuipers, E.J.; Janssen, H.L.; van der Molen, R.G.; Boonstra, A. Intrahepatic regulatory $\mathrm{T}$ cells are phenotypically distinct from their peripheral counterparts in chronic HBV patients. Clin. Immunol. 2008, 129, 419-427. [CrossRef] [PubMed]

159. Bonelli, M.; Savitskaya, A.; Steiner, C.W.; Rath, E.; Smolen, J.S.; Scheinecker, C. Phenotypic and functional analysis of CD4+ CD25Foxp3+ T cells in patients with systemic lupus erythematosus. J. Immunol. 2009, 182, 1689-1695. [CrossRef]

160. Radhakrishnan, S.; Cabrera, R.; Schenk, E.L.; Nava-Parada, P.; Bell, M.P.; Van Keulen, V.P.; Marler, R.J.; Felts, S.J.; Pease, L.R. Reprogrammed FoxP3+ T regulatory cells become IL-17+ antigen-specific autoimmune effectors in vitro and in vivo. J. Immunol. 2008, 181, 3137-3147. [CrossRef]

161. Komatsu, N.; Okamoto, K.; Sawa, S.; Nakashima, T.; Oh-hora, M.; Kodama, T.; Tanaka, S.; Bluestone, J.A.; Takayanagi, H. Pathogenic conversion of Foxp3+ T cells into TH17 cells in autoimmune arthritis. Nat. Med. 2014, 20, 62-68. [CrossRef]

162. Veiga-Parga, T.; Sehrawat, S.; Rouse, B.T. Role of regulatory T cells during virus infection. Immunol. Rev. 2013, 255, 182-196. [CrossRef]

163. Suvas, S.; Azkur, A.K.; Kim, B.S.; Kumaraguru, U.; Rouse, B.T. CD4+CD25+ regulatory T cells control the severity of viral immunoinflammatory lesions. J. Immunol. 2004, 172, 4123-4132. [CrossRef]

164. Trandem, K.; Anghelina, D.; Zhao, J.; Perlman, S. Regulatory T cells inhibit T cell proliferation and decrease demyelination in mice chronically infected with a coronavirus. J. Immunol. 2010, 184, 4391-4400. [CrossRef] [PubMed] 
165. Mucida, D.; Park, Y.; Kim, G.; Turovskaya, O.; Scott, I.; Kronenberg, M.; Cheroutre, H. Reciprocal TH17 and regulatory T cell differentiation mediated by retinoic acid. Science 2007, 317, 256-260. [CrossRef] [PubMed]

166. Coombes, J.L.; Siddiqui, K.R.; Arancibia-Carcamo, C.V.; Hall, J.; Sun, C.M.; Belkaid, Y.; Powrie, F. A functionally specialized population of mucosal CD103+ DCs induces Foxp3+ regulatory T cells via a TGF-beta and retinoic acid-dependent mechanism. J. Exp. Med. 2007, 204, 1757-1764. [CrossRef]

167. Martinez, N.E.; Karlsson, F.; Sato, F.; Kawai, E.; Omura, S.; Minagar, A.; Grisham, M.B.; Tsunoda, I. Protective and detrimental roles for regulatory T cells in a viral model for multiple sclerosis. Brain Pathol. 2014, 24, 436-451. [CrossRef] [PubMed]

168. Nakae, S.; Iwakura, Y.; Suto, H.; Galli, S.J. Phenotypic differences between Th1 and Th17 cells and negative regulation of Th1 cell differentiation by IL-17. J. Leukoc. Biol. 2007, 81, 1258-1268. [CrossRef] [PubMed]

169. Murray, P.D.; McGavern, D.B.; Lin, X.; Njenga, M.K.; Leibowitz, J.; Pease, L.R.; Rodriguez, M. Perforin-dependent neurologic injury in a viral model of multiple sclerosis. J. Neurosci. 1998, 18, 7306-7314. [CrossRef]

170. Palma, J.P.; Lee, H.G.; Mohindru, M.; Kang, B.S.; Dal Canto, M.; Miller, S.D.; Kim, B.S. Enhanced susceptibility to Theiler's virus-induced demyelinating disease in perforin-deficient mice. J. Neuroimmunol. 2001, 116, 125-135. [CrossRef]

171. Pena Rossi, C.; McAllister, A.; Fiette, L.; Brahic, M. Theiler's virus infection induces a specific cytotoxic T lymphocyte response. Cell. Immunol. 1991, 138, 341-348. [CrossRef]

172. Lindsley, M.D.; Thiemann, R.; Rodriguez, M. Cytotoxic T cells isolated from the central nervous systems of mice infected with Theiler's virus. J. Virol. 1991, 65, 6612-6620. [CrossRef]

173. Rivera-Quinones, C.; McGavern, D.; Schmelzer, J.D.; Hunter, S.F.; Low, P.A.; Rodriguez, M. Absence of neurological deficits following extensive demyelination in a class I-deficient murine model of multiple sclerosis. Nat. Med. 1998, 4, 187-193. [CrossRef]

174. Sun, D.; Qin, Y.; Chluba, J.; Epplen, J.T.; Wekerle, H. Suppression of experimentally induced autoimmune encephalomyelitis by cytolytic T-T cell interactions. Nature 1988, 332, 843-845. [CrossRef] [PubMed]

175. Borrow, P.; Tonks, P.; Welsh, C.J.; Nash, A.A. The role of CD8+T cells in the acute and chronic phases of Theiler's murine encephalomyelitis virus-induced disease in mice. J. Gen. Virol. 1992, 73, 1861-1865. [CrossRef] [PubMed]

176. Fiette, L.; Aubert, C.; Brahic, M.; Rossi, C.P. Theiler's virus infection of beta 2-microglobulin-deficient mice. J. Virol. 1993, 67, 589-592. [CrossRef] [PubMed]

177. Pullen, L.C.; Miller, S.D.; Dal Canto, M.C.; Kim, B.S. Class I-deficient resistant mice intracerebrally inoculated with Theiler's virus show an increased T cell response to viral antigens and susceptibility to demyelination. Eur. J. Immunol. 1993, 23, $2287-2293$. [CrossRef]

178. Rodriguez, M.; Dunkel, A.J.; Thiemann, R.L.; Leibowitz, J.; Zijlstra, M.; Jaenisch, R. Abrogation of resistance to Theiler's virus-induced demyelination in H-2b mice deficient in beta 2-microglobulin. J. Immunol. 1993, 151, $266-276$.

179. Begolka, W.S.; Haynes, L.M.; Olson, J.K.; Padilla, J.; Neville, K.L.; Dal Canto, M.; Palma, J.; Kim, B.S.; Miller, S.D. CD8-deficient SJL mice display enhanced susceptibility to Theiler's virus infection and increased demyelinating pathology. J. Neurovirol. $2001,7,409-420$.

180. Dethlefs, S.; Brahic, M.; Larsson-Sciard, E.L. An early, abundant cytotoxic T-lymphocyte response against Theiler's virus is critical for preventing viral persistence. J. Virol. 1997, 71, 8875-8878. [CrossRef]

181. Nicholson, S.M.; Dal Canto, M.C.; Miller, S.D.; Melvold, R.W. Adoptively transferred CD8+ T lymphocytes provide protection against TMEV-induced demyelinating disease in BALB/c mice. J. Immunol. 1996, 156, 1276-1283.

182. Borson, N.D.; Paul, C.; Lin, X.; Nevala, W.K.; Strausbauch, M.A.; Rodriguez, M.; Wettstein, P.J. Brain-infiltrating cytolytic T lymphocytes specific for Theiler's virus recognize $\mathrm{H} 2 \mathrm{Db}$ molecules complexed with a viral VP2 peptide lacking a consensus anchor residue. J. Virol. 1997, 71, 5244-5250. [CrossRef]

183. Dethlefs, S.; Escriou, N.; Brahic, M.; van der Werf, S.; Larsson-Sciard, E.L. Theiler's virus and Mengo virus induce cross-reactive cytotoxic T lymphocytes restricted to the same immunodominant VP2 epitope in C57BL/6 mice. J. Virol. 1997, 71, 5361-5365. [CrossRef]

184. Lyman, M.A.; Lee, H.G.; Kang, B.S.; Kang, H.K.; Kim, B.S. Capsid-specific cytotoxic T lymphocytes recognize three distinct $\mathrm{H}-2 \mathrm{D}(\mathrm{b})$-restricted regions of the BeAn strain of Theiler's virus and exhibit different cytokine profiles. J. Virol. 2002, 76, 3125-3134. [CrossRef] [PubMed]

185. Pullen, L.C.; Kim, B.S. Identification of a suitable target cell line for Theiler's murine encephalomyelitis virus specific CTL. FASEB J. 1991, 5, A1094.

186. Baenziger, J.; Hengartner, H.; Zinkernagel, R.; Cole, G. Induction or prevention of immunopathological disease by cloned cytotoxic T cell lines specific for lymphocytic choriomeningitis virus. Eur. J. Immunol. 1986, 16, 387-393. [CrossRef] [PubMed]

187. Doherty, P.; Allan, J.; Lynch, F.; Ceredig, R. Dissection of an inflammatory process induced by CD8+ T cells. Immulol. Today 1990, 11, 55-59. [CrossRef]

188. Huber, S.A.; Lodge, P.A. Coxsackievirus B-3 myocarditis in Balb/c mice. Evidence for autoimmunity to myocyte antigens. Am. J. Pathol. 1984, 116, 21-29. [PubMed]

189. Chang, Y.; Nadigel, J.; Boulais, N.; Bourbeau, J.; Maltais, F.; Eidelman, D.H.; Hamid, Q. CD8 positive T cells express IL-17 in patients with chronic obstructive pulmonary disease. Respir. Res. 2011, 12, 43. [CrossRef]

190. Kuang, D.M.; Peng, C.; Zhao, Q.; Wu, Y.; Zhu, L.Y.; Wang, J.; Yin, X.Y.; Li, L.; Zheng, L. Tumor-activated monocytes promote expansion of IL-17-producing CD8+ T cells in hepatocellular carcinoma patients. J. Immunol. 2010, 185, 1544-1549. [CrossRef] [PubMed] 
191. Myoung, J.; Kang, H.S.; Hou, W.; Meng, L.; Dal Canto, M.C.; Kim, B.S. Epitope-specific CD8+ T cells play a differential pathogenic role in the development of a viral disease model for multiple sclerosis. J. Virol. 2012, 86, 13717-13728. [CrossRef] [PubMed]

192. Roos, R.P.; Stein, S.; Routbort, M.; Senkowski, A.; Bodwell, T.; Wollmann, R. Theiler's murine encephalomyelitis virus neutralization escape mutants have a change in disease phenotype. J.Virol. 1989, 63, 4469-4473. [CrossRef]

193. Zurbriggen, A.; Fujinami, R.S. A neutralization-resistant Theiler's virus variant produces an altered disease pattern in the mouse central nervous system. J.Virol. 1989, 63, 1505-1513. [CrossRef]

194. Roos, R.P.; Nalefski, E.A.; Nitayaphan, S.; Variakojis, R.; Singh, K.K. An isoelectric focusing overlay study of the humoral immune response in Theiler's virus demyelinating disease. J. Neuroimmunol. 1987, 13, 305-314. [CrossRef]

195. Mattson, D.H.; Roos, R.P.; Arnason, B.G. Comparison of agar gel electrophoresis and isoelectric focusing in multiple sclerosis and subacute sclerosing panencephalitis. Ann. Neurol. 1981, 9, 34-41. [CrossRef]

196. Cash, E.; Bandeira, A.; Chirinian, S.; Brahic, M. Characterization of B lymphocytes present in the demyelinating lesions induced by Theiler's virus. J. Immunol. 1989, 143, 984-988. [PubMed]

197. Pachner, A.R.; Li, L.; Lagunoff, D. Plasma cells in the central nervous system in the Theiler's virus model of multiple sclerosis. J. Neuroimmunol. 2011, 232, 35-40. [CrossRef] [PubMed]

198. Crane, M.A.; Jue, C.; Mitchell, M.; Lipton, H.; Kim, B.S. Detection of restricted predominant epitopes of Theiler's murine encephalomyelitis virus capsid proteins expressed in the lambda gt11 system: Differential patterns of antibody reactivity among different mouse strains. J. Neuroimmunol. 1990, 27, 173-186. [CrossRef]

199. Kim, B.S.; Choe, Y.K.; Crane, M.A.; Jue, C.R. Identification and localization of a limited number of predominant conformationindependent antibody epitopes of Theiler's murine encephalomyelitus virus. Immunol. Lett. 1992, 31, 199-205. [CrossRef]

200. Cameron, K.; Zhang, X.; Seal, B.; Rodriguez, M.; Njenga, M.K. Antigens to viral capsid and non-capsid proteins are present in brain tissues and antibodies in sera of Theiler's virus-infected mice. J. Virol. Methods 2001, 91, 11-19. [CrossRef]

201. Rodriguez, M.; Kenny, J.J.; Thiemann, R.L.; Woloschak, G.E. Theiler's virus-induced demyelination in mice immunosuppressed with anti-IgM and in mice expressing the xid gene. Microb. Pathog. 1990, 8, 23-35. [CrossRef]

202. Kang, B.S.; Palma, J.P.; Lyman, M.A.; Dal Canto, M.; Kim, B.S. Antibody response is required for protection from Theiler's virus-induced encephalitis in C57BL/ 6 mice in the absence of CD8(+) T cells. Virology 2005, 340, 84-94. [CrossRef] [PubMed]

203. Gilli, F.; Li, L.; Campbell, S.J.; Anthony, D.C.; Pachner, A.R. The effect of B-cell depletion in the Theiler's model of multiple sclerosis. J. Neurol. Sci. 2015, 359, 40-47. [CrossRef]

204. McCright, I.J.; Fujinami, R.S. Lack of correlation of Theiler's virus binding to cells with infection. J. Neurovirol. 1997, 3 (Suppl. 1), S68-S70.

205. Chesnut, R.G.; Grey, H.M. Antigen presentation by B cells and its significance in T-B interactions. Adv. Immunol. 1986, 39, 51-94. [PubMed]

206. Santiago-Raber, M.L.; Baudino, L.; Izui, S. Emerging roles of TLR7 and TLR9 in murine SLE. J. Autoimmun. 2009, 33, 231-238. [CrossRef] [PubMed]

207. Mills, K.H. TLR-dependent T cell activation in autoimmunity. Nat. Rev. Immunol. 2011, 11, 807-822. [CrossRef]

208. Kiefer, K.; Oropallo, M.A.; Cancro, M.P.; Marshak-Rothstein, A. Role of type I interferons in the activation of autoreactive B cells. Immunol. Cell Biol. 2012, 90, 498-504. [CrossRef]

209. Kishimoto, T. Interleukin-6: From basic science to medicine-40 years in immunology. Annu. Rev. Immunol. 2005, $23,1-21$. [CrossRef] [PubMed]

210. Kuno, K.; Matsushima, K. The IL-1 receptor signaling pathway. J. Leukoc. Biol. 1994, 56, 542-547. [CrossRef] [PubMed]

211. Fujinami, R.S.; Zurbriggen, A.; Powell, H.C. Monoclonal antibody defines determinant between Theiler's virus and lipid -like structures. J. Neuroimmunol. 1988, 20, 25-32. [CrossRef]

212. Tsunoda, I.; Kuang, L.Q.; Kobayashi-Warren, M.; Fujinami, R.S. Central nervous system pathology caused by autoreactive CD8+ T-cell clones following virus infection. J. Virol. 2005, 79, 14640-14646. [CrossRef] [PubMed]

213. Fujinami, R.S.; Zurbriggen, A. Is Theiler's murine encephalomyelitis virus infection of mice an autoimmune disease? APMIS 1989, 97, 1-8. [CrossRef]

214. Miller, S.D.; Vanderlugt, C.L.; Begolka, W.S.; Pao, W.; Neville, K.L.; Yauch, R.L.; Kim, B.S. Epitope spreading leads to myelinspecific autoimmune responses in SJL mice chronically infected with Theiler's virus. J. Neurovirol. 1997, 3 (Suppl. 1), S62-S65.

215. Miller, D.J.; Njenga, M.K.; Murray, P.D.; Leibowitz, J.; Rodriguez, M. A monoclonal natural autoantibody that promotes remyelination suppresses central nervous system inflammation and increases virus expression after Theiler's virus-induced demyelination. Int. Immunol. 1996, 8, 131-141. [CrossRef] [PubMed]

216. Drescher, K.M.; Pease, L.R.; Rodriguez, M. Antiviral immune responses modulate the nature of central nervous system (CNS) disease in a murine model of multiple sclerosis. Immunol. Rev. 1997, 159, 177-193. [CrossRef] [PubMed]

217. Asakura, K.; Miller, D.J.; Pease, L.R.; Rodriguez, M. Targeting of IgMkappa antibodies to oligodendrocytes promotes CNS remyelination. J. Neurosci. 1998, 18, 7700-7708. [CrossRef] [PubMed]

218. Palma, J.P.; Park, S.H.; Kim, B.S. Treatment with lipopolysaccharide enhances the pathogenicity of a low-pathogenic variant of Theiler's murine encephalomyelitis virus. J. Neurosci. Res. 1996, 45, 776-785. [CrossRef]

219. Fuller, A.; Yahikozawa, H.; So, E.Y.; Dal Canto, M.; Koh, C.S.; Welsh, C.J.; Kim, B.S. Castration of male C57L/J mice increases susceptibility and estrogen treatment restores resistance to Theiler's virus-induced demyelinating disease. J. Neurosci. Res. 2007, 85, 871-881. [CrossRef] 
220. Sin, J.; Mangale, V.; Thienphrapa, W.; Gottlieb, R.A.; Feuer, R. Recent progress in understanding coxsackievirus replication, dissemination, and pathogenesis. Virology 2015, 484, 288-304. [CrossRef] [PubMed]

221. Chen, J.; Subbarao, K. The Immunobiology of SARS*. Annu. Rev. Immunol. 2007, 25, 443-472. [CrossRef]

222. Hu, B.; Guo, H. Characteristics of SARS-CoV-2 and COVID-19. Nat. Rev. Microbiol. 2021, 19, 141-154. [CrossRef] 